\title{
Co-evolution between Trust in Teachers and Higher Education Enabled by ICT Advancement - A Suggestion to ICT Growing Economies
}

\author{
Chihiro Watanabe \\ Faculty of Information Technology, University of Jyväskylä, Finland. \\ International Institute for Applied Systems Analysis (IIASA), Austria. \\ Kashif Naveed \\ Faculty of Information Technology, University of Jyväskylä, Finland.

\section{Pekka Neittaanmäki} \\ Faculty of Information Technology, University of Jyväskylä, Finland.
}

\begin{abstract}
In light of the increasing significance of trust-based higher education towards digitally-rich learning environments, co-evolution dynamism between trust in teachers and higher education enabled by ICT advancement was analyzed. Using the rate of trust in teachers for good education in the Global Teacher Status Index, together with statistics on higher education level and ICT advancement, an empirical numerical analysis of 20 countries was attempted. It was identified that while ICT advanced countries have constructed a co-evolution between ICT, higher education and trust, ICT growing countries have not succeeded due to a vicious cycle between ICT and trust. Finland's educational success can be attributed to this co-evolution while an education productivity paradox can be attributed to a disengagement. It is suggested that steady ICT advancement by making full utilization of external resources in digitally-rich learning environments can be essential to ICT growing countries for their higher education. A new approach for constructing the foregoing co-evolution in a systematic way was thus explored.
\end{abstract}

Keywords: Trust in teachers, Blended learning, Educational productivity paradox, Pedagogical love, Logistic growth

\section{INTRODUCTION}

While better educational outcomes are a strong predictor of economic growth, wealth and spending on education alone are no guarantee for better educational outcomes (OECD, 2011). While Finland demonstrates world most outstanding educational performance (e.g., WEF, 2013), no single thing can explain outstanding performance. Teachers' capacity to teach in classrooms and work collaboratively in professional communities has been systematically built through academic teacher education (Sahlberg, 2010). It is generally pointed out that "pedagogical love," relationship between students, teachers, parents and even educational administrators based on trust can be the secret to Finland's educational success (Stehlik, 2016).

The importance of the concept of trust in the educational context has

Journal of Technology Management for Growing Economies

Vol. 7, No. 2

October 2016 pp. $85-116$

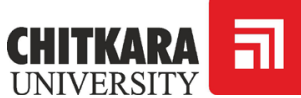

(C) 2016 by Chitkara University. All Rights Reserved. 
Watanabe, $\mathrm{C}$.

Naveed, K.

Neittaanmäki, P. been increasingly recognized, and a growing body of literature supports the idea that trustworthy relationships between teachers and students are fundamentally important, both for students' ability to learn and effective teaching. With a trustful relationship, teachers can anticipate students' behavior and feel encouraged to actively participate in lessons without the fear of being compromised by the teacher (Schlte-Pelkum et al., 2014). Trust in the education environment provides students an opportunity to take initiative in their learning (Brown et al., 2007).

Contrary to these expectation, Varkey Gems Foundation who conducted international comparative survey on the global teacher status index claimed that "There is no correlation between trusting teachers and educational outcomes. For example, Brazil places the most trust in their teachers, yet has one of the lowest learning outcomes in the 21 countries surveyed" (VGF, 2014).

These contradictory debate can largely be attributed to the dramatic advancement of Information and Communication Technology (ICT) that provides significant impact on education environment (UNESCO, 2003; Jeferry et al., 2014) together with some resistance (Oreg et al., 2015).

Despite teachers' resistance to the use of advanced technology in education, dramatic advancement of ICT leveraged rapid increase in blended learning. Technology has increased the breadth and depth of access to education. This is significant because it has been a hallmark of western education that colocation in time and space of teachers, students, and resources is the sine qua non of education (Jeffery et al., 2014).

Learning environment as a broader setting than a classroom, as the context in which learning is situated, has become widespread. This environment consists of the physical and digital setting in which learners carry out their activities, including all the tools, documents and other artefacts to be found in that setting. Besides the physical and digital setting, it includes the sociocultural setting for such activities. The role of ICT in the innovative learning environment which should have the necessary technological, social and educational affordances to provide opportunities to learn has thus become critical (Zitter et al., 2012).

In this innovative learning environment, teachers need to be adequately prepared to implement a state-of-the-art ICT curriculum. Programs of professional development for teachers are most effective if directed to the stage of ICT development reached by schools (Anderson et al., 2002). In this context, we note that hybrid model that combines reinforcement learning with supervised learning outperforms a pure supervised learning model and a pure reinforcement learning model (Henderson et al., 2008). Cross-fertilization leading to new forms of learning that integrate aspects of both formal and

Journal of Technology Management for Growing Economies, Volume 7, Number 2, October 2016 
informal learning which interweave learning and working processes to benefit from the strengths of both formal, school-based learning and real-life experience (Zitter et al., 2012).

These trends have emerged blended learning and reminded us the significance of trust in teachers in accomplishing this learning as a hybrid model in the innovative learning environment.

However, despite the clear demonstration of the benefits of using technology in education, there continues to be a marked reluctance by academics to engage with online learning (Anderson, 2008). It was revealed that teachers were much less positive than their students about the learning benefits of an online learning component (Heaton-Shrestha et al., 2009). Teachers' status can easily be eroded, as learners can compare teacher-designed resources with video lectures from across the world on similar topics and chat directly with experts in the field through their blogs (Greener, 2009). The potential for such comparisons inclined teachers to be reluctant to expose themselves to ridicule or unflattering comparisons (Jeffery et al., 2014).Teachers claim that technology has no beneficial effect on learning and is even instrumental in maintaining students in a state of semi-disengagement (Heaton-Shrestha et al., 2009). Teachers who fail to recognize the benefits of online learning are less likely to create effective blended courses (Jeffery et al., 2014). In addition, many educators share experiences of students that are apathetic, as well as unwilling to engage in the learning experience and ultimately fail. These students have mastered withdrawing from the classroom as a defense (Brown et al., 2007).

Peslak (2005), utilizing US's annual survey of computers, ICT, and other technology, as well as library resources in 2000-2001, assessed their contribution to educational test scores and revealed that ICT factors did not show consistent, positive relationships with higher educational scores. He interpreted one possible reason of this educational productivity paradox can be more time was spent with computers than actual education and learning activities

These contradiction on the light and shade of blended learning can be attributed to distinct phases of ICT development in the innovative learning environment. UNESCO's Institute for Information Technology has evaluated the degree to which ICT has been integrated in an educational system by dividing four distinct phases: (i) emerging, (ii) applying, (iii) infusing, and (iv) transforming (UNESCO, 2003). These stages offer us a lens through which we can observe how ICT has leveraged incremental and deep change in learning environments.

Confronting digitally-rich learning environments, in order to make effective
Co-evolution between Trust in Teachers 
Watanabe, $\mathrm{C}$. Naveed, K. Neittaanmäki, P. utilization of this potential for higher education, key task for the nation is how to smoothly shifting from traditional teaching practice to blended learning by realizing distinct phases of ICT integration in an education system.

Systems conflict generally emerges in the transition of these phases before reaching to transformation phase. Success of transformation largely depended on the rigidity or flexibility of the school curriculum (Groff, 2013), which is strongly influenced by cultural, societal and institutional factors (Anderson et al., 2002). Therefore, optimal balance between ICT and older educational technologies reflecting national and regional cultures are key components of the organization's strategy (Anderson et al., 2002; UNESCO, 2003).

While foregoing reviews highlight the increasing significance of trustbased higher education towards digitally-rich learning environments and elastic institutional system enabling smooth transformation from traditional teaching practice to blending learning, none have analyzed co-evolution dynamism between trust in teachers and higher education enabled by ICT advancement and a possible fear of disengagement in the transition phase which is considered the fundamental source of the contradictory problem.

This paper, aiming at exploring a new approach for constructing the foregoing co-evolution in a systematic way, using the rate of trust in teachers for good education in the Global Teacher Status Index, together with statistics on higher education level and ICT advancement, attempted an empirical numerical analysis of 20 countries on this co-evolution dynamism.

Section 2 analyzes co-evolutionary dynamism in 20 countries. Structural source of the contrast of co-evolution and disengagement in 20 countries is analyzed in Section 3. Section 4 briefly summarizes noteworthy findings, implications, and suggestions for future works.

\section{CO-EVOLUTIONARY DYNAMISM BETWEEN TRUST IN TEACHERS, HIGHER EDUCATION AND ICT ADVANCEMENT}

\section{ICT Driven Education Development}

Dramatic advancement of the Internet beyond anticipation in terms of its diffusion speed and scope has led to ICT-driven economic development trajectory worldwide. Consequently, economic development (e.g., GDP per capita) trajectory in 100 nations in the world (see Appendix 1) can be depicted by a logistic growth function initiated by the advancement of ICT (e.g., Networked Readiness Index: NRI ) (Zhao et al., 2013). Given the strong correlation between economic development and enhancement of higher education level as demonstrated in Fig. 1, contribution of advancement of ICT to enhancement of education level can be depicted by a logistic growth function as demonstrated in Figs. 2 and 3 (see Appendix 2).

Journal of Technology Management for Growing Economies, Volume 7, Number 2, October 2016 


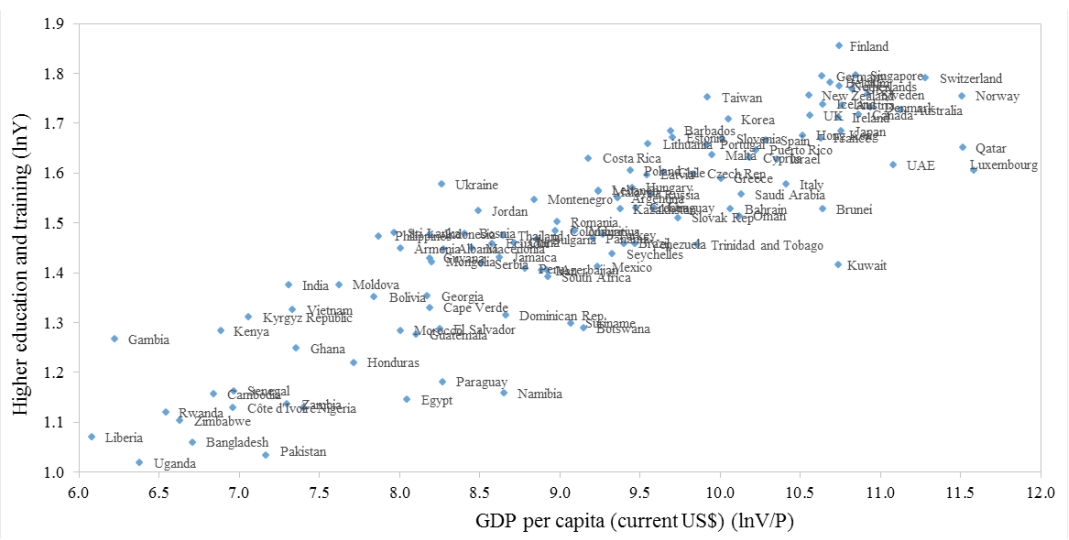

Co-evolution between Trust in Teachers

Figure 1: Correlation between Economic Development and Enhancement of Education Level in 120 Countries (2013).

$$
\ln Y=\underset{(6.03)}{0.294+0.130 \ln \frac{V}{P}-0.230 D} \quad \text { adj. } R^{2} 0.850
$$

$D$ : Luxembourg, Kuwait, Egypt, Botswana, Paraguay, Pakistan, Namibia, Suriname $=1$, others $=0$.

Figures in parenthesis indicate t-statistics: all significant at the $1 \%$ level.

Sources: The Global Information Technology Report 2013 (World Economic Forum, 2013).

The World Economic Outlook Database (IMF, 2013).

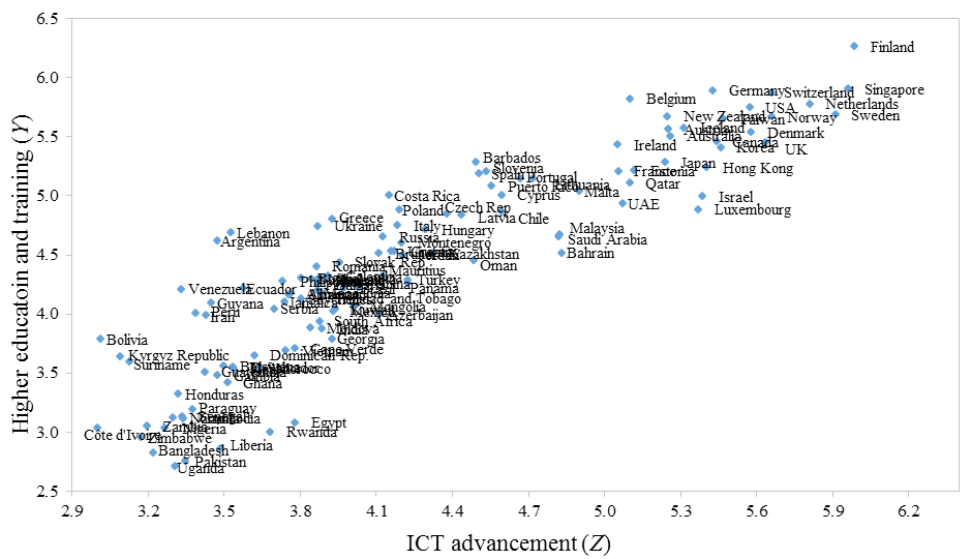

Figure 2: ICT-driven Educational Development in 120 Countries (2013). Sources: The Global Information Technology Report 2013 (World Economic Forum, 2013). The Global Competitiveness Report 2013-2014 (World Economic Forum, 2013). 
Watanabe, $\mathrm{C}$.

Naveed, K.

Neittaanmäki, P.

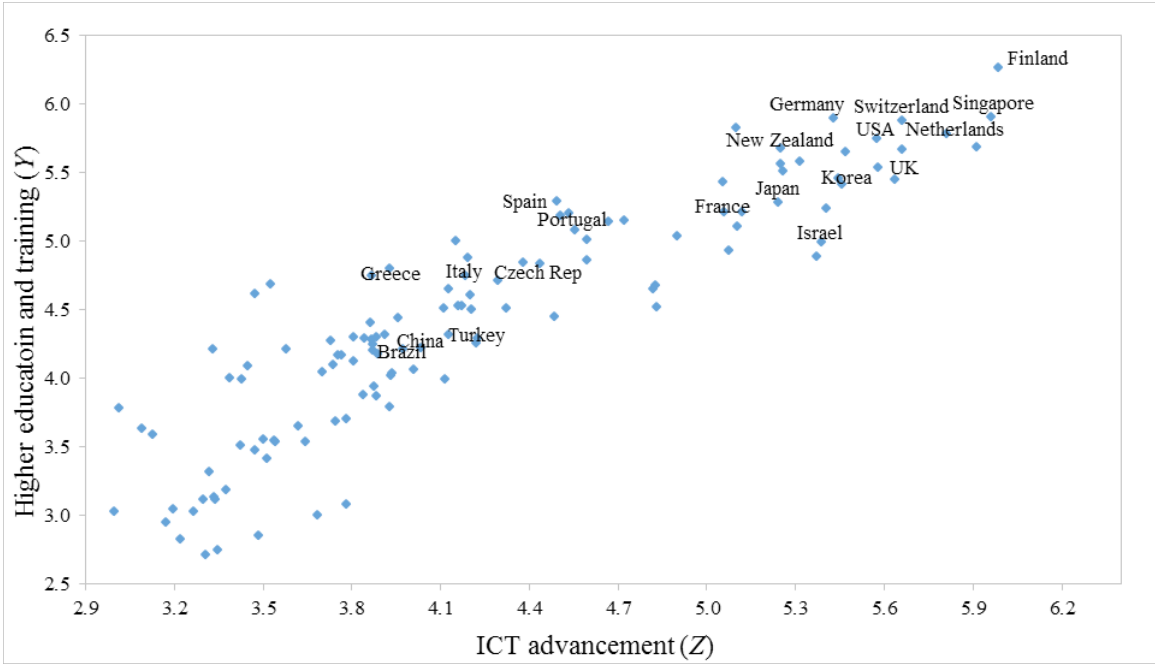

Figure 3: ICT-driven Educational Development in 20 Selected Countries (2013).

Sources: The Global Information Technology Report 2013 (World Economic Forum, 2013). The Global Competitiveness Report 2013-2014 (World Economic Forum, 2013).

\section{Stage of ICT Advancement}

Thus, advancement of ICT plays significant role in enhancing education level worldwide. With such understanding in mind, Fig. 4 compares advancement of ICT in 100 countries.

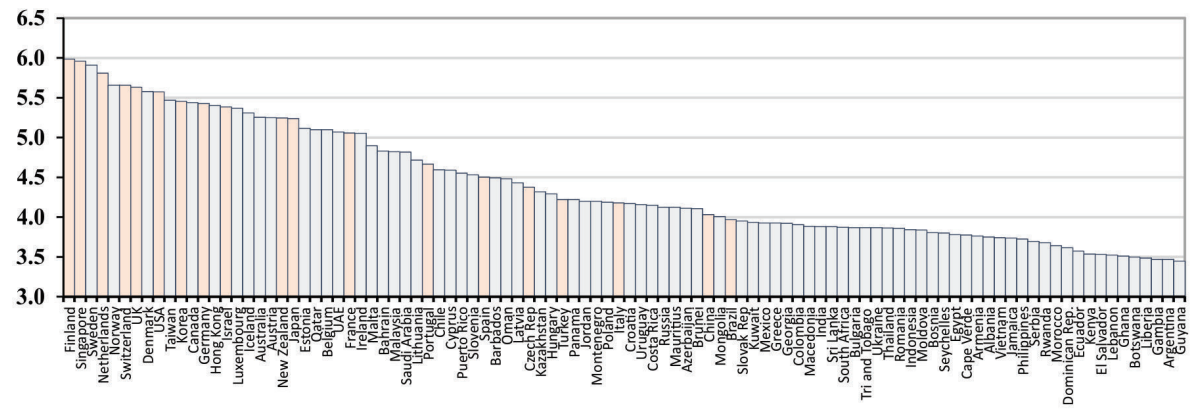

Figure 4: Level of ICT Advancement by NRI in 100 Countries (2013). Sources: The Global Information Technology Report 2013 (World Economic Forum, 2013).

On the basis of the foregoing global ICT advancement and its contribution to enhancing higher education together with trust in teachers, this paper 
focuses on the analysis of a co-evolutionary dynamism between trust in teachers and higher education enabled by ICT advancement taking 20 countries for which reliable trust in teachers data are available (see Appendix 3).

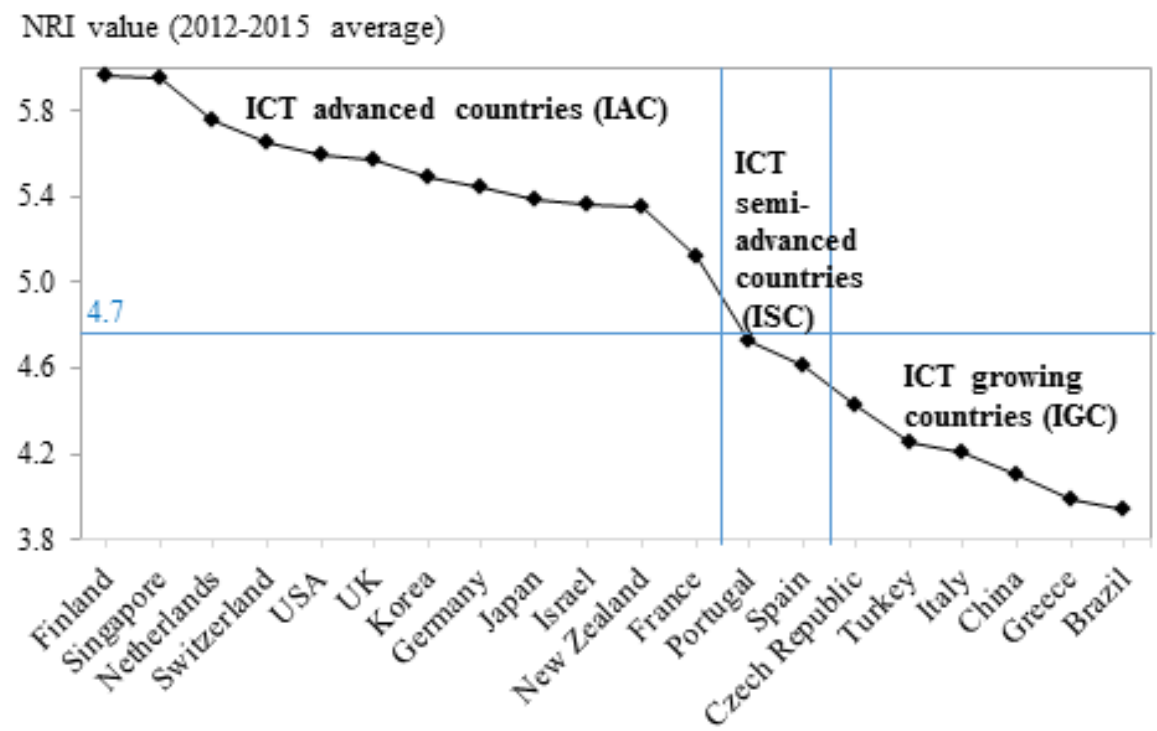

Figure 5: Focuses on comparison of level of ICT advancement in 20 countries by taking average of NRI between 2012-2015.

Looking at Fig. 5 we note that stage of ICT advancement in the world can be classified into ICT advanced countries (IAC), ICT semi-advanced countries (ISC), and ICT growing countries (IGC) as follows:

IAC: Finland, Singapore, Netherlands, Switzerland, USA, UK, Korea, Germany, Japan, Israel, New Zealand and France;

ISC: Portugal, Spain;

IGC: Chez Republic, Turkey, Italy, China, Greece, Brazil.

Given the significant role of ICT advancement in enhancing education level as reviewed earlier, this stage plays decisive role in education as blend learning has been played significant role in enhancing education and dependency on this learning corresponds to the stage of ICT advancement (UNESCO, 2003; Groff, 2013).
Co-evolution between Trust in Teachers 
Watanabe, C.

Naveed, K.

Neittaanmäki, P.

92

NRI value (2012-2015 average)

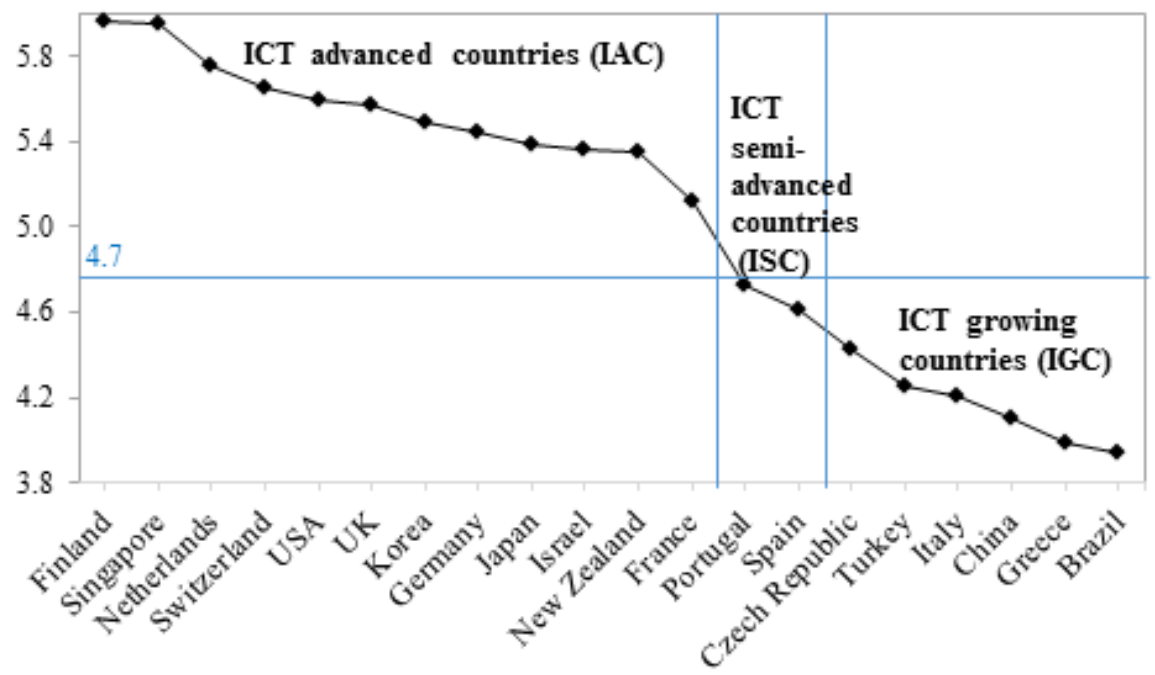

Figure 5: Level of ICT Advancement by NRI in 20 Countries (2012-2015 average).

Source: The Global Information Technology Report 2013 (World Economic Forum, 2013).

Fig. 6. Compares the level of higher education in 20 countries.

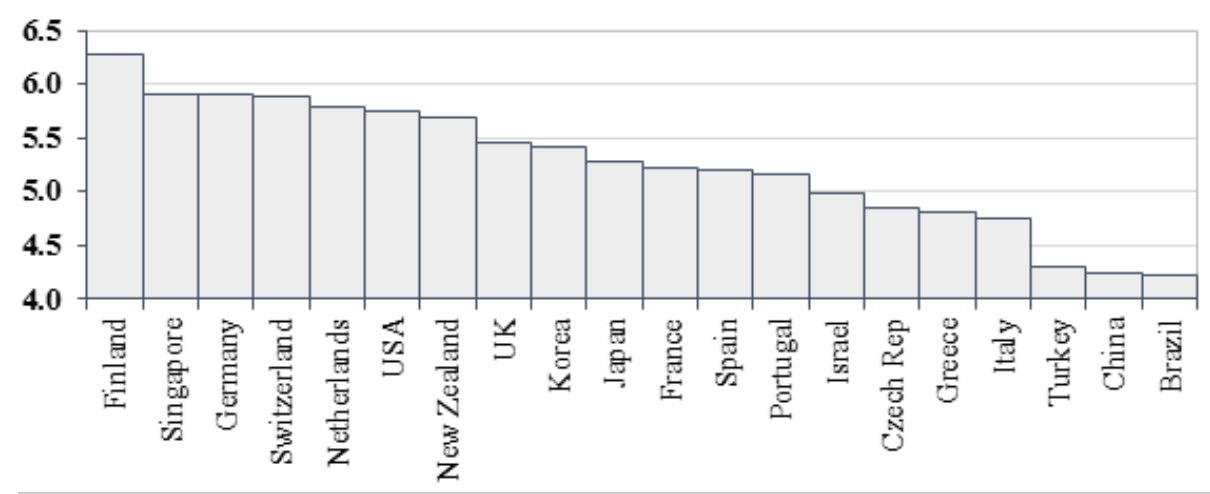

Figure 6: Level of Higher Education in 20 Countries (2013).

Source: The Global Competitiveness Report 2013-2014 (World Economic Forum, 2013).

Fig. 7. Compares the degree of trust in teachers in 20 countries.

Journal of Technology Management for Growing Economies, Volume 7, Number 2, October 2016 


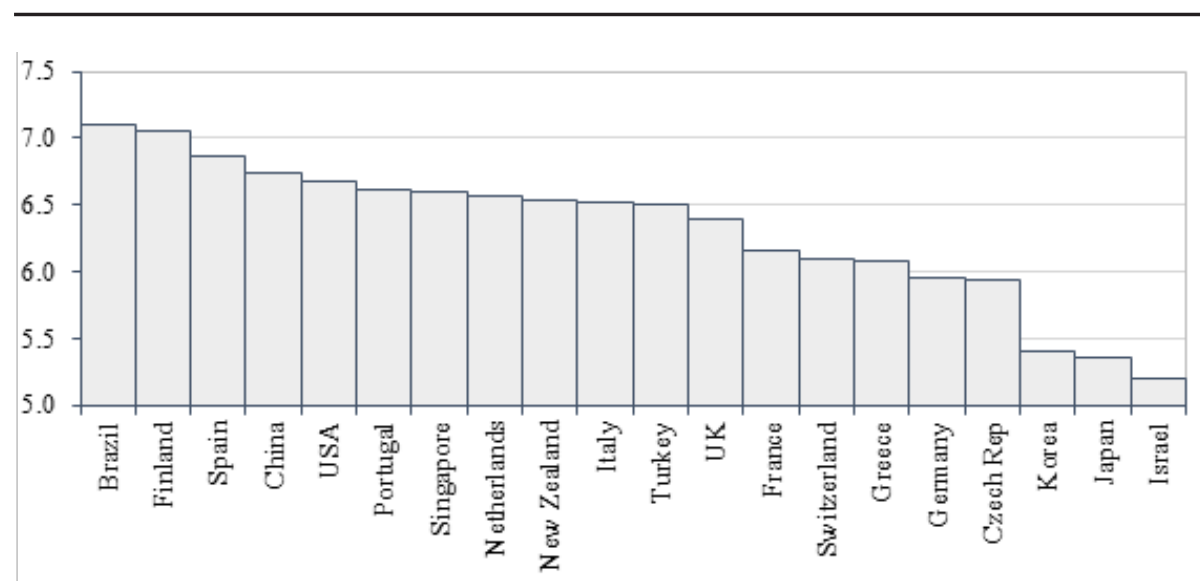

Co-evolution between Trust in Teachers

Figure 7: Level of Trust in Teachers to Deliver a Good Education in 20 Countries (2013).

Source: 2013 Global Teacher Status Index (Varkey GEMS Foundation, 2014).

With a hypothetical understanding that successful shift from traditional teaching practice to blended learning towards digitally-rich learning environments can largely be attributed to a co-evolutionary dynamics between ICT advancement, higher education and trust in teachers (Watanabe et al, 2015, 2016), this co-evolution in 20 countries is analyzed. Tables A3-5 compares advancement of ICT, higher education level, and trust in teachers in 20 countries. Table A6 demonstrates composition of higher education level.

\section{Co-evolutionary Advancement between Trust in Teachers and Higher Education}

Utilizing the foregoing data, first, co-evolution between advancement in teachers and higher education level in 20 countries was analyzed by dividing 20 countries into ICT advanced 12 countries (IAC), ICT semi-advanced 2 countries (ISC), and ICT growing 6 countries (IGC).

Result of the analysis is illustrated in Fig. 8. Looking at Fig. 8 we note that, contrary to Varkey Gems Foundation's observation that "There is no correlation between trusting teachers and educational outcomes" (VGF, 2014), there are strong correlations between them depending on the stage of ICT advancement. While higher education level depends on trust in teachers in IAC and ISC, this correlation is opposite in IGC. In IGC, it is anticipated that trust in teachers spoils students education resulting in declining their educational level. 
Watanabe, $\mathrm{C}$.

Naveed, K.

Neittaanmäki, P.

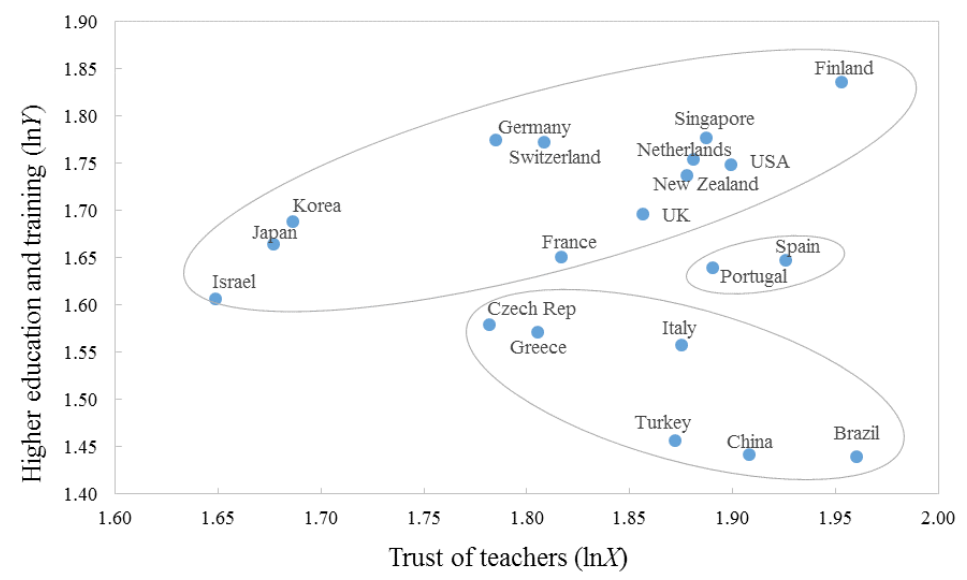

Figure 8: Correlation between Trust in Teachers and Higher Education Level in 20 Countries (2013).

$D_{1}, D_{2}, D_{3}$ : Coefficient dummy variables corresponding to IAC, ISC and IGC, respectively.

Figures in parenthesis indicate t-statistics: all significant at the $1 \%$ level.

Inspired by these observations, Fig. 9 analyzes the effects of the enhancement of higher education level on increasing in trust in teachers. Fig. 9 also demonstrates that while higher education demonstrates a positive correlation with trust in teachers in IAC and ISC, it is opposite in IGC. While higher education stimulates trust in teachers in IAC and ISC, it results in decreasing the trust in IGC.

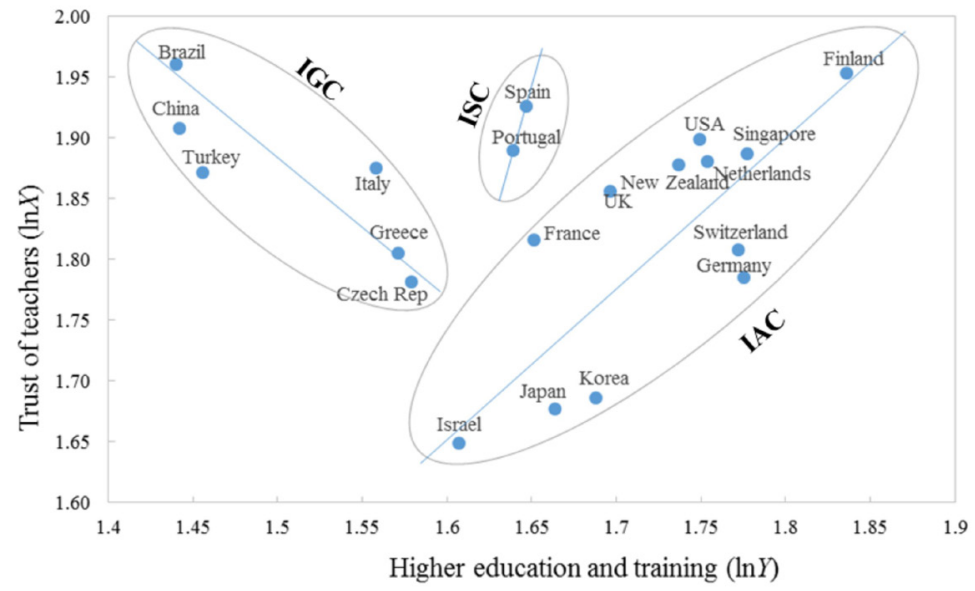

Figure 9: Correlation between Higher Education Level and Trust in Teachers in 20 Countries (2013).

Journal of Technology Management for Growing Economies, Volume 7, Number 2, October 2016 
$\ln X=\underset{\left(-1.51^{14}\right.}{-0.631+1.406} \quad\left(5 D_{1} \ln Y+1.545 D_{2} \ln Y-0.815 D_{3} \ln Y+3.726 D_{3}+0.114 D \quad\right.$ adj. $R^{2} 0.707$

$D$ : Dummy variables (France, $\mathrm{UK}=1$, others $=0$ ).
Co-evolution

between Trust in

Teachers

Figures in parenthesis indicate t-statistics: all significant at the $1 \%$ level, except $*$ and $^{\#}$ at the $2 \%$ and $15 \%$ level, respectively.

These analyses in Figs. 8 and 9 demonstrate that increase in trust in teachers stimulates higher education, which in turn induces trust in teachers leading to a co-evolution between them in IAC and ISC, both disengage in IGC resulting in a vicious cycle.

\section{Co-evolutional Advancement between ICT and Trust in Teachers}

Inspired by the foregoing findings on the co-evolution between trust in teachers and higher education in IAC and ISC, and their disengagement in IGC, correlation between ICT advancement and trust in teachers was analyzed next.

Fig. 10 demonstrates the result of the analysis on the correlation between ICT advancement and trust in teachers in 20 countries also dividing by ICT advancement stage.

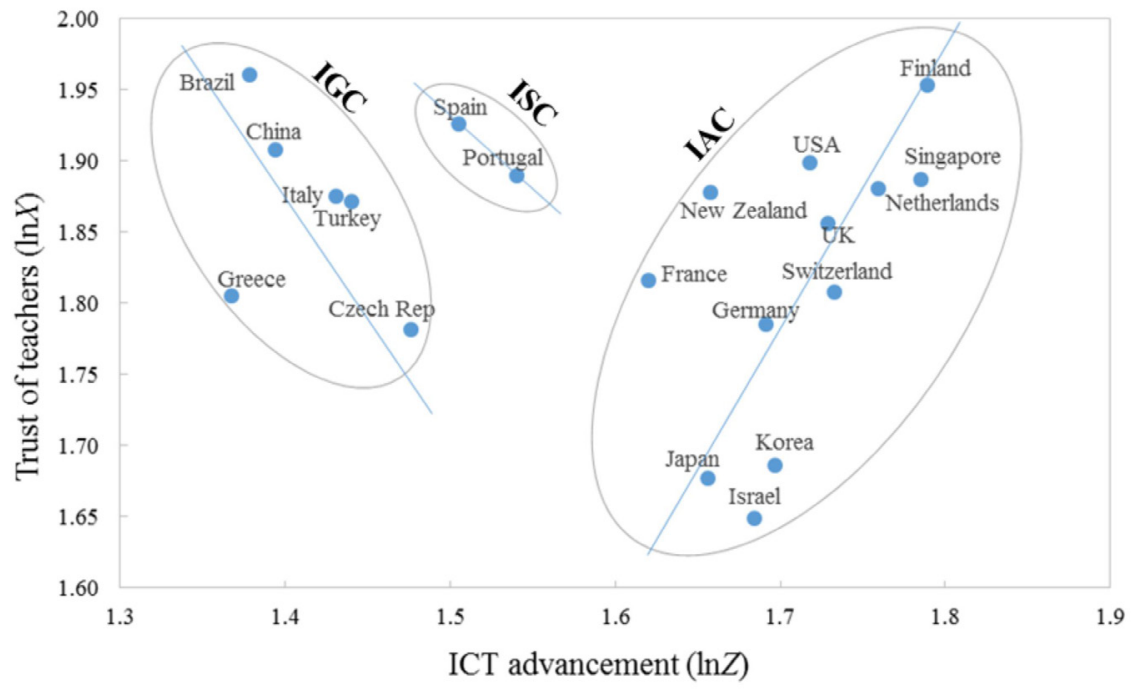

Figure 10: Correlation between ICT Advancement and Trust in Teachers in 20 Countries (2013).

$D$ : Dummy variables (Japan, Israel, Czech Rep., Korea $=1$, others $=0$ ).

Figures in parenthesis indicate t-statistics: all significant at the $1 \%$ level, except $* *$ at the $3 \%$ level. 
Watanabe, $\mathrm{C}$. Naveed, K.

Neittaanmäki, P.
Looking at Fig. 10 we note that while advancement of ICT induces increase in trust in teachers in IAC, it demonstrates opposite not only in IGC but also in ISC. Advancement of ICT contributes to increase in trust in teachers in IAC as generally anticipated in digitally-rich learning environments. However, surprising to see, advancement of ICT loses trust in teachers not only in IGC but also in ISC.

Inspired by such surprising observation, Fig. 11 analyzes the effect of trust in teachers on ICT advancement.

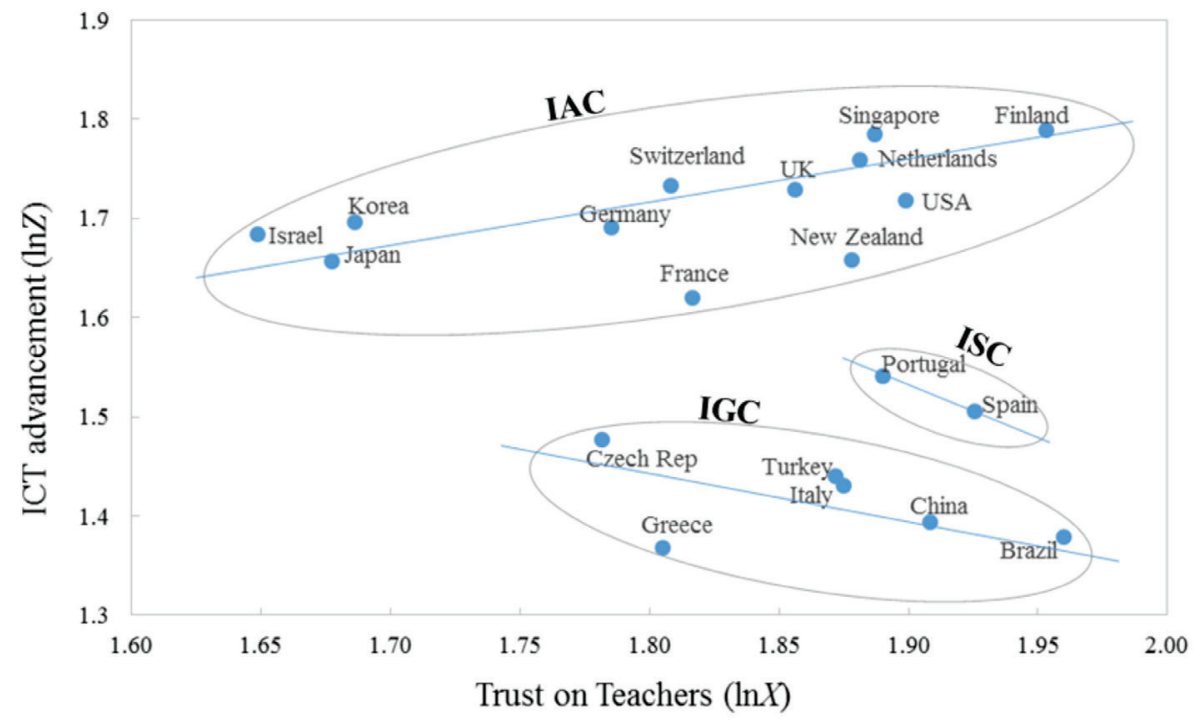

Figure 11: Correlation between Trust in Teachers and ICT Advancement in 20 Countries (2013).

$D$ : Dummy variables (France, New Zealand, Greece $=1$, others $=0$ )

$$
\ln Z=\underset{(10.03)}{2.535+0.360} \quad D_{1} \ln X-\underset{(-4.00)}{0.530} D_{2} \ln X-0.591 D_{3} \ln X-1.461 D_{1}-0.099 D \quad \text { adj. } R^{2} 0.982
$$

Fig. 11 demonstrates positive correlation between trust in teachers and ICT advancement also in IAC, similar to Fig. 10 it changed to negative in ISC and IGC.

These analyses in Figs. 10 and 11 demonstrate a co-evolution between ICT advancement and trust in teachers in IAC similar to its co-evolution between trust in teachers and higher education. This is opposite in IGC similar to its preceding disengagement. In case of ISC, contrary to its co-evolution between trust in teachers and higher education, it changed to disengagement in case of the correlation between ICT advancement and trust in teachers.

Journal of Technology Management for Growing Economies, Volume 7, Number 2, October 2016 
This unexpected contrast between co-evolution of trust and higher education, and disengagement of ICT advancement and trust in ISC suggests a possible system conflict in the transition of distinct phases of ICT advancement towards digitally-rich learning environments.

\section{Co-evolution and Disengagement between ICT, Education Level, and Trust in Teachers}

On the basis of the foregoing analyses, co-evolution and disengagement between ICT advancement, higher education level and trust in teachers in IAC, ISC and IGC can be summarized as illustrated in Fig. 12.

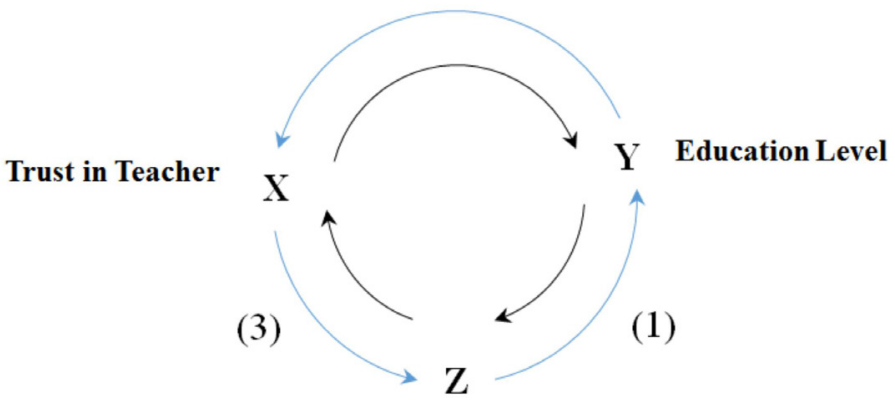

ICT Advancement

\begin{tabular}{|l|c|c|c|}
\hline & $\begin{array}{l}\text { ICT advanced coun- } \\
\text { tries (IAC) }\end{array}$ & $\begin{array}{l}\text { ICT semi-advanced } \\
\text { countries (ISC) }\end{array}$ & $\begin{array}{l}\text { ICT growing } \\
\text { countries (IGC) }\end{array}$ \\
\hline (1) $\mathrm{Z}$ and $\mathrm{Y}$ & + & + & + \\
\hline$(2) \mathrm{Y}$ and $\mathrm{X}$ & + & + & - \\
\hline$(3) \mathrm{X}$ and $\mathrm{Z}$ & + & - & - \\
\hline
\end{tabular}

Figure 12: Co-evolution and Disengagement between ICT, Educational Level, and Trust in Teachers in 20 Countries Depending on ICT Advancement.

+ : Co-evolution (virtuous cycle), - : Disengagement (vicious cycle)

As summarized in Fig. 12, while correlation between ICT advancement and higher education was demonstrated a co-evolution in all IAC, ISC and IGC, correlation between higher education and trust demonstrates contrast between co-evolution in IAC and ISC, and IGC. Similarly, correlation between trust and ICT advancement demonstrates contrast between co-evolution in IAC and disengagement in ISC and IGC. 
Watanabe, C.

Naveed, K.

Neittaanmäki, P.

98

STRUCTURALSOURCE OFTHECONTRASTOFCO-EVOLUTION AND DISENGAGEMENT BETWEEN ICT, EDUCATION LEVEL, AND TRUST IN TEACHERS

Inspired by the preceding findings with respect to contrasting co-evolution and disengagement depending on the ICT development stage (Cowen, 2011), its structural source was analyzed.

\section{Logistic Growth in ICT-driven Higher Education}

As illustrated in Figs. 2 and 3, advancement of ICT contributes to enhancement of educational level in line with a following logistic growth function:

$$
\begin{aligned}
& \frac{d Y}{d Z}=a Y\left(1-\frac{Y}{N}\right) \\
& Y=\frac{N}{1+b e^{-a Z}}
\end{aligned}
$$

where $Y$ : Higher education level, $N$ : Upper limit (carrying capacity), $Z$ : ICT advancement level, $a$ : velocity of diffusion, $b$ : initial state of education level.

This logistic growth result in a bi-polarization as illustrated in Fig. 13 (Tokumasu et al., 2009; Zhao et al., 2013; Watanabe et al., 2014, see details in Appendix 4).

$$
y=\frac{a N}{\frac{a Y}{a Z}}=a N \cdot \frac{d Z}{d Y}=\frac{N^{2}}{Y(N-Y)}
$$

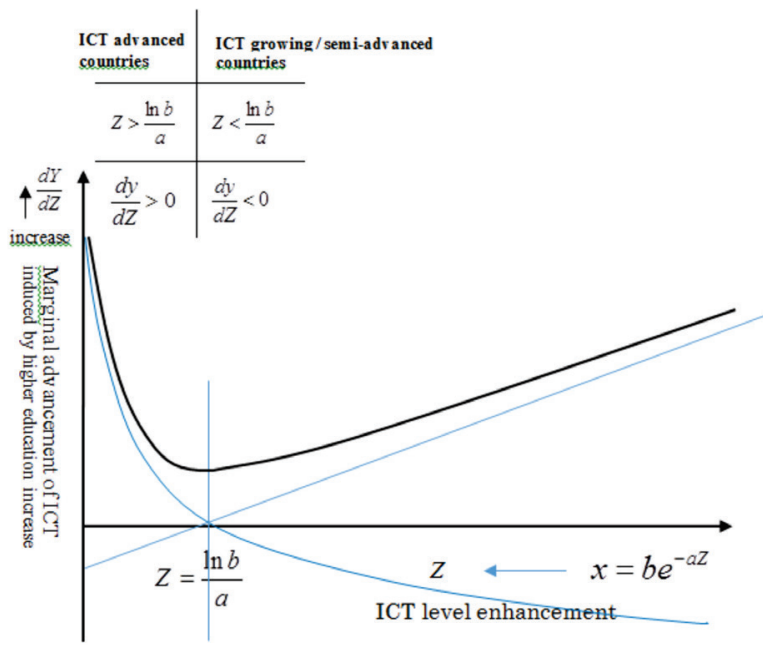

Figure 13: Bipolarization of ICT-driven Higher Education.

This Figure illustrates $x$ (ICT level enhance) and $y$ (marginal education level enhance stimulated by ICT advancement which is the reverse of marginal

Journal of Technology Management for Growing Economies, Volume 7, Number 2, October 2016 
advancement of ICT induced by higher education) increase toward the origin of coordinates. The Figure indicates that while marginal advancement of ICT increases induced by higher education $(\mathrm{d} Z / \mathrm{d} Y)$ increase when ICT advancement level exceeds certain threshold $(Z>\ln b / a)$, it decreases when ICT advancement level remains lower than this threshold $(Z<\ln b / a)$.

Realizing bi-polarization nature of the logistic growth that governs ICTdriven higher education trajectory in 100 countries towards digitally-rich learning environment as reviewed in Fig. 11, positions of 20 selected countries in the trajectory can be identified as illustrated in Fig. 14.

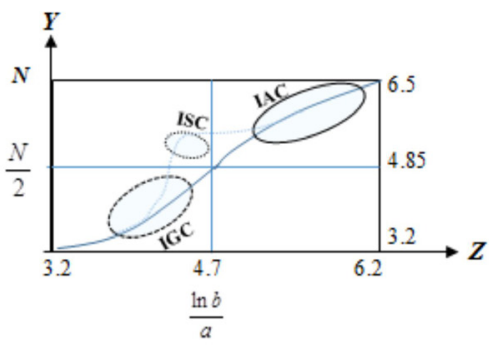

$$
Y=\frac{N}{1+b e^{-a z}}
$$

\begin{tabular}{|l|l|l|}
\hline $\begin{array}{c}\text { 1CTh lesvel } \\
\text { lexel }\end{array}$ & $Y>\frac{N}{2}$ & $Y<\frac{N}{2}$ \\
\hline$Z>\frac{\ln b}{a}$ & IAC & \\
\hline$z<\frac{\ln b}{a}$ & ISC & IGC \\
\hline
\end{tabular}

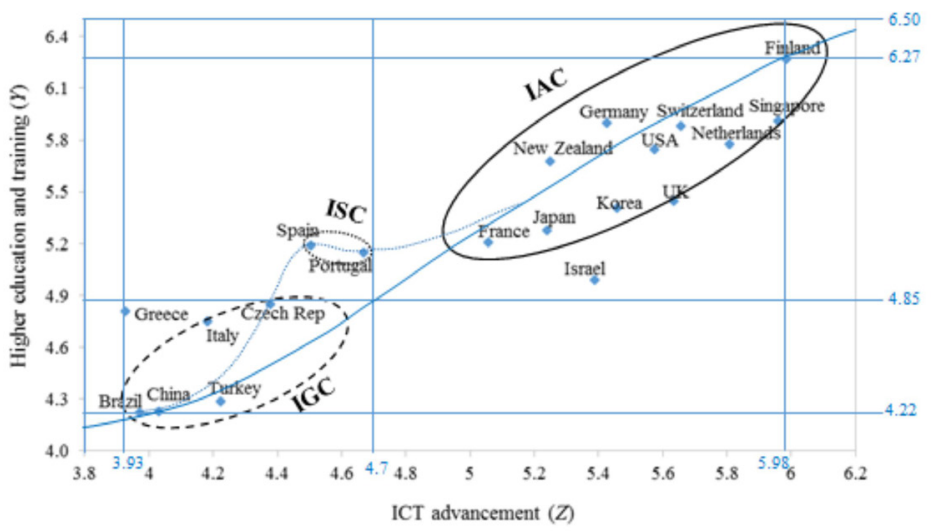

Figure 14: Positions of 20 Countries in ICT-driven Higher Education Trajectory (2013).

\section{ICT Elasticity to Trust in Teachers Depending on ICT Advancement}

On the basis of the identification of positions of 20 countries in the digitally rich learning environments with bi-polarization fatality, peculiar behavior of ISC in a transition from IGC to IAC that, against expectation, trust in teachers decrease as ICT advances can be explained.

ICT advancement $(Z)$ elasticity to trust in teachers $(X)$ can be decomposed as follows (see details Appendix 4):

Journal of Technology Management for Growing Economies, Volume 7, Number 2, October 2016
Co-evolution between Trust in Teachers 
Watanabe, C.

Naveed, K.

Neittaanmäki, P.
$Z$ elasticity Positive $Y$ elasticity Marginal advance Education

to $X \quad$ factor $\quad$ to $X \quad$-ment of ICT level

$$
\frac{d \ln X}{d \ln Z}=A \cdot \frac{d \ln X}{d \ln Y} \cdot \frac{d y}{d Z} \cdot \frac{1}{(2 Y-N)}
$$

Therefore, ICT elasticity to trust in teachers in 20 countries can be classified as Table 1 depending on their development stage.

Table 1 Classification of ICT Elasticity to Trust in 20 Countries (2013)

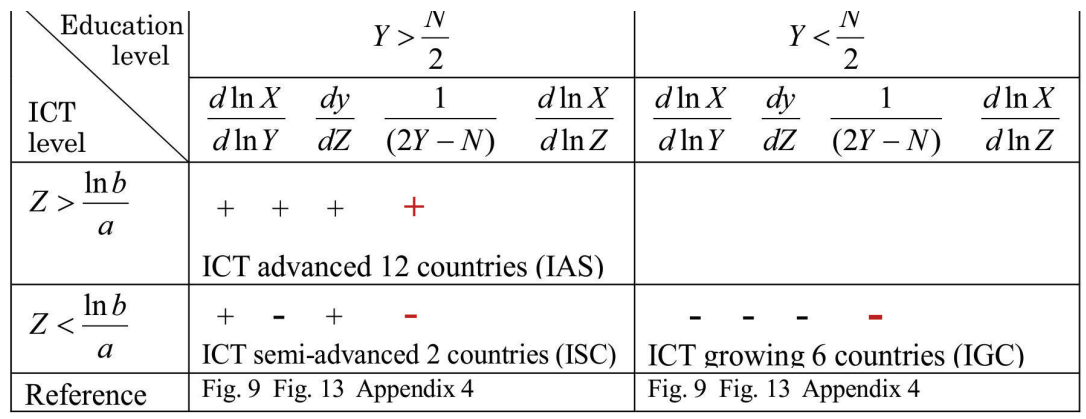

This explains the reason why ISC takes peculiar behavior against general expectation as trust decreases as ICT advances.

\section{ICT Elasticity to Higher Education Depending on ICT Advancement}

This finding leads to another noteworthy finding that advancement of ICT may decline higher education depending on the position in the digitally-rich learning environments.

ICT advancement $(Z)$ elasticity to higher education $(Y)$ can be decomposed as follows:

Therefore, similar to Table 5, ICT elasticity to higher education in 20 countries can be classified as Table 2 depending on their development stage.

Table 2 Classification of ICT Elasticity to Higher Education in 20 Countries (2013)

\begin{tabular}{|c|c|c|c|c|c|c|}
\hline \multirow{3}{*}{$\begin{array}{l}\text { Education } \\
\text { level } \\
\text { ICT } \\
\text { level }\end{array}$} & \multicolumn{3}{|c|}{$Y>\frac{N}{2}$} & \multicolumn{3}{|c|}{$Y<\frac{N}{2}$} \\
\hline & $d \ln X$ & $d \ln Y$ & $d \ln Y$ & $d \ln X$ & $d \ln Y$ & $d \ln Y$ \\
\hline & $d \ln Z$ & $d \ln X$ & $d \ln Z$ & $d \ln Z$ & $d \ln X$ & $d \ln Z$ \\
\hline \multirow{2}{*}{$Z>\frac{\ln b}{a}$} & + & + & + & & & \\
\hline & \multicolumn{3}{|c|}{ ICT advanced 12 countries (IAC) } & & & \\
\hline \multirow{2}{*}{$Z<\frac{\ln b}{a}$} & \multirow{2}{*}{\multicolumn{2}{|c|}{ ICT semi-advanced 2}} & \multirow{2}{*}{$\begin{array}{c}- \\
\text { countries }\end{array}$} & \multirow{2}{*}{\multicolumn{2}{|c|}{6 coun }} & + \\
\hline & & & & & & s (IGC) \\
\hline Reference & Table 1 & Fig. 8 & & Table 1 & Fig. 8 & \\
\hline
\end{tabular}

Journal of Technology Management for Growing Economies, Volume 7, Number 2, October 2016 
This reveals unexpected behavior beyond general understanding that advancement of ICT declines higher education level in particular position in the digitally-rich learning environments as has been observed in ISC in its transition from IGC to IAC.

\section{Effect of Blended Learning and Teachers' Resistance to It}

Prompted by the foregoing empirical findings, particularly by peculiar behavior of ISC in transition from IGC to IAC as, against general anticipation, declining its higher educational level as ICT advancement proceeds, effect of the shift to blended learning and teacher's resistance against this shift was reviewed as they demonstrates higher educational level decline in the transition from traditional technical practice.

Widespread use of the Web and other Internet technologies in education has exploded in the last 2 decades (Chen et al., 2010). Fig. 15 illustrates scheme of ICT advancement contributing to higher education. An increasing locomotive of this trend can be blended learning (Jeffrey et al., 2014).

Under such circumstances, advancement of ICT's contributed to higher education can be developed in a hybrid manner consisting of traditional teaching practice and blended learning as illustrated in Fig. 15 (Mischan et al., 2015).

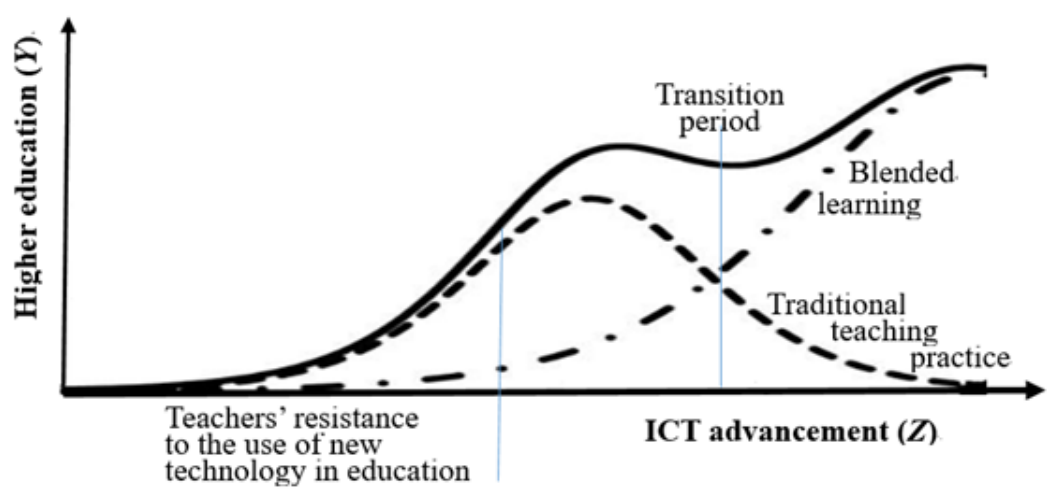

Figure 15: Scheme of ICT Advancement Contribution to Higher Education by Stage.

While there exists strong teachers' resistance to the use of new technology in education that impedes the dependency on blended learning (Anderson, 2008 ), once attaining certain higher education level, increasing dependency

Journal of Technology Management for Growing Economies, Volume 7, Number 2, October 2016
Co-evolution between Trust in Teachers

\section{1}


Watanabe, $\mathrm{C}$. Naveed, K.

Neittaanmäki, P. on blended learning exceeds such resistance (Jeferry et sl., 2014) leading to a co-evolution between advancement of ICT and further dependency on blended learning as is demonstrated by the strong correlation between ICT advancement and higher dependency on the Internet access in schools (Fig. 16).

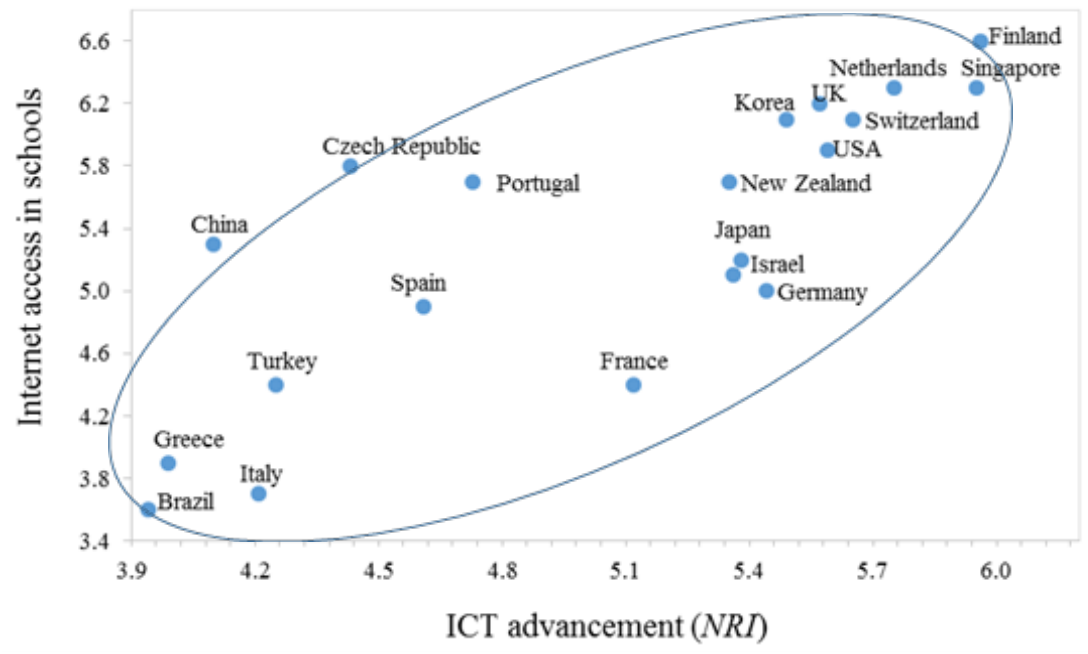

Figure 16: Correlation between ICT Advancement and Internet Access in Schools in 20 Countries (2013).

Sources: The Global Information Technology Report 2013 (WEF, 2013). The Global Competitiveness Report 2013-2014 (WEF, 2013).

Looking at Fig. 16 we note the significant correlation between ICT advancement and the Internet access in schools as a proxy of the advancement of blended learning.

However, before constructing such a co-evolution, transition to blend learning results in higher education decline at its transition period as demonstrated in Fig. 15.

Looking at Fig. 14 carefully, we note that ISC is in the transition from IGC to IAC and, contrary to normal trajectory as demonstrated in IGC and IAC, demonstrates slightly negative coefficient. This corresponds to this decline in the transition period.

\section{Co-evolution and Disengagement Reassessed}

This finding urges us to reassess the co-evolution and disengagement dynamism between ICT, higher education level, and trust in teachers in 20 countries summarized in Fig. 12 to that of classified in Fig. 17. 


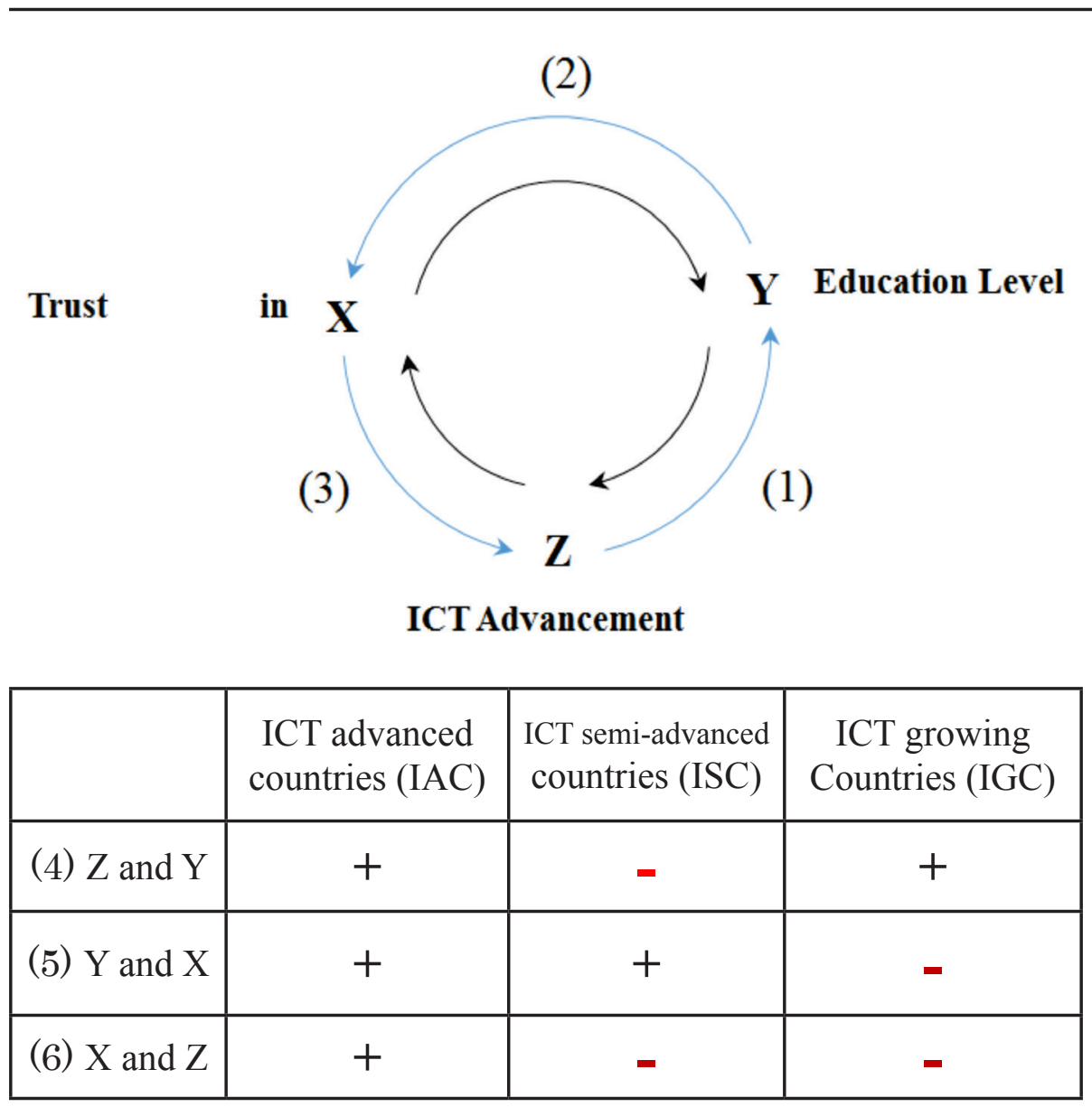

Fig. 17. Co-evolution and Disengagement between ICT, Educational Level, and Trust in Teachers in 20 Countries Depending on ICT Advancement - Reassessed.

+ : Co-evolution (virtuous cycle), - : Disengagement (vicious cycle)

This reassessment identifies state of digitally-rich learning environments and subsequent co-evolution and disengagement for 20 countries depending on their ICT advancement. This identification provides insightful suggestions to respective countries for their priority countermeasures for constructing a co-evolution between ICT advancement, higher education enhancement and trust in teachers increase as indicated in Fig. 18. 
Watanabe, C.

Naveed, K.

Neittaanmäki, P.

\begin{tabular}{|c|c|c|c|c|}
\hline & & \multicolumn{2}{|c|}{$\begin{array}{l}\text { State of digitally-rich learning environments and } \\
\text { subsequent co-evolution }\end{array}$} & Priority countermeasures \\
\hline 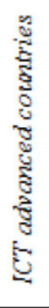 & 3 & & $\begin{array}{l}\text { Shifted to DILE } \\
\text { Constructed } \\
\text { co-evolutionary dynamism } \\
\text { between } Z, Y \text { andX. }\end{array}$ & $\begin{array}{l}\text { Successive innovation for } \\
\text { further DILE (so as to } \\
\text { correspond to decline in } \\
\text { marginal ICT enhancement } \\
\text { of education } \\
\qquad\left(\frac{d}{d z} \cdot \frac{d y}{d z}<0\right)\end{array}$ \\
\hline 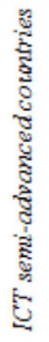 & $\underset{3}{3}$ & & $\begin{array}{l}\text { Transition from TTLE to } \\
\text { DILE } \\
\text { Unsuccessful co-evolution } \\
\text { due to a vicious cycle } \\
\text { between } Z \text { and } Y \text {. }\end{array}$ & Accelerate the shift to DILE. \\
\hline 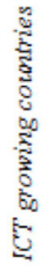 & S & & $\begin{array}{l}\text { Remain } T T L E \\
\text { Disengagement due to a } \\
\text { mismatch between } Z \text { and } X \text {. }\end{array}$ & $\begin{array}{l}\text { Effective utilization of } \\
\text { external resources for steady } \\
\text { advancement of } Z\end{array}$ \\
\hline
\end{tabular}

DILE: Digitally-rich Innovative Learning Environments

TTLE: Traditional Teaching and Learning Environments

$X$ : Trust in Teachers $Y$ : Education Level $Z$ : ICT Advancement

Figure 18: State of Digitally-rich Learning Environments, Subsequent Co-evolution and Priority Countermeasures.

\section{CONCLUSION}

In light of the increasing significance of trust-based higher education towards digitally-rich learning environments, co-evolution dynamism between trust in teachers and higher education enabled by ICT advancement was analyzed.

Using the rate of trust in teachers for good education in the Global Teacher Status Index, together with statistics on higher education level and ICT advancement, an empirical numerical analysis of 20 countries was attempted. 
Noteworthy findings include:

1. ICT-driven trust-based higher education has becoming crucial for nation's competitiveness towards digitally-rich learning environments (DILE),

2. In such environments, ICT advancement, higher education, and trust in teachers have closely interweaved each other,

3. 20 Countries examined can be divided into 3 groups depending on their ICT advancement as: ICT advanced countries (IAC), ICT semi-advanced countries (ISC), and ICT growing countries (IGC),

4. Given the significant shift from traditional teaching practice to blended learning towards DILE, state of the country in this shift has become crucial for its performance.

5. IAC has shifted to DILE and constructed a co-evolutionary dynamism between ICT, higher education and trust,

6. ISC is in the transition from traditional teaching and learning environments (TTLE) to DILE and unsuccessful co-evolution due to a vicious cycle between ICT advancement and higher educational level enhancement, and

7. IGC remains TTLE and suffers disengagement due to a mismatch between ICT advancement and trust in teachers.

These findings provide insightful suggestions to respective countries for their successful co-evolution depending on their state:

1. For IAC, successive innovation for further DILE is required so as to correspond to decline in marginal productivity of ICT advancement for higher education enhancement,

2. Timely transfer of its co-evolutionary resources to IGC thereby its vigor can be harnessed in a programmatic way,

3. For ISC, clear understanding of the state of transition from IGC to IAC should be maintained,

4. Given the peculiar phenomena particular to this transition that advancement of ICT declines higher education, optimal supplement compensating this decline should be taken,

5. Effective utilization of external resources for accelerating the shift to DILE should be taken,

6. For IGC, Effective utilization of external resources for steady advancement of ICT should be taken priority basis, and

7. Consistent effort for steady shift to DILE should be taken in a program-

Journal of Technology Management for Growing Economies, Volume 7, Number 2, October 2016
Co-evolution

between Trust in

Teachers 
Watanabe, $\mathrm{C}$. Naveed, K.

Neittaanmäki, P.

matic way while maintaining optimal balance with TTLE. This paper explored a new approach for constructing a co-evolution between ICT advancement, higher education enhancement and trust in teachers increase in a systematic way. Further work should focus on in-depth analysis of institutional systems accelerating or impeding the construction of this coevolution. Further analysis of peculiar behavior at a transition in digitally-rich learning environments will be another important subject to be undertaken. For that, wider empirical analysis taking broader countries should be considered.

\section{ENDNOTE}

1. Blended learning is a formal education program in which student learns at least in part through delivery of content and instruction via digital and online media with some

2. Networked readiness index (nri) measured by the world economic forum (wef) measures worldwide advancement of ict by computing following four dimensions: (i) environment (political and regulatory environment, business and innovation environment, (ii) readiness (infrastructure, digital content, and affordability, (iii) usage (individual usage, business usage and government usage, and (iv) impact (economic impact and social impact).

3. Based on the criteria introduced by global teacher status index (the varkey gems foundation, 2014) as representing each major continent and also representative of different strands of educational systems (see appendix 3 ).

4. Degree of $\%$ increase in trust in teachers by means of $1 \%$ increase in ict advancement.

5. Internet access in schools is one of the key component of higher education and training level as demonstrated in table a6.

\section{REFERENCES}

Anderson, J. and van Weert, T. (eds), 2002. Information and Communication Technology in Education: A Curriculum for Schools and Programme of Teacher Development. UNESCO, Paris.

Anderson, C. (2008) Barriers and Enabling Factors in Online Teaching. International Journal of Learning, 14 (12), 241-246.

Brown, D. and Skinner, D.A. (2007) "Brown-skinner Model for Building Trust with At-risk Students", National Forum of Applied Educational Research Journal, 20 (3) 1-7.

Chen, P.S.D., Lambert, A.D. and Guidry K.R. (2010) "Engaging Online Learners: The Impact of Web-based Learning Technology on College Student Engagement", Computer and Education, 54 (4), 1222-1232. http://dx.doi.org/10.1016/j.compedu.2009.11.008

Cowen, T. (2011) “The Great Stagnation”, Dutton, New York.

Greener, S. (2009) "E-Modelling: Helping Learners to Develop Sound e-learning Behaviours Electronic", Journal of e-Learning, 7 (3), 265-272.

Groff, J.S. (2013) "Technology-rich Innovative Learning Environments", Report on OECD Innovative Learning Environments Project.

Journal of Technology Management for Growing Economies, Volume 7, Number 2, October 2016 
Heaton-Shrestha, C., May, S. And Burke, L. (2009) "Student Retention in Higher Education: What Role for Virtual Learning Environments?”, Journal of Further and Higher Education, 33 (1), 83-92. http://dx.doi.org/10.1080/03098770802645189.

Henderson, J., Lemon, O. and Georgila, K. (2008) "Hybrid Reinforcement and Supervised Learning of Dialogue Policies from Fixed Data Sets", Computational Linguistics, 34 (4) 485-511.

IMF, (2013) "The World Economic Outlook Database”, IMF, Washington.

Jeffrey, L.M., Milne, J. And Suddaby, G. (2014) "Blended Learning: How Teachers Balance the Blend of Online and Classroom Components", Journal of Information Technology Education, 13, 121-140.

Mischan, MM., Passos, J.R.S., Pinho, S.Z. and Carvalho, L.R. (2015) "Inflextion and Stability Points of Diphasic Logistic Analysis of Growth", Scientia Agricola, 72 (3), 1-9. http:// dx.doi.org/10.1590/0103-9016-2014-0212.

OECD (2010) "Are the New Millennium Learners Making the Grade?", Technology Use and Educational Performance in PISA 2006. OECD, Paris.

OECD (2011) "PISA 2009 Results: Students On Line-Digital Technologies and Performance” (Volume VI). OECD, Paris.

Oreg, A. and Goldenbelg, J. (2015) "Resistance to Innovation: Its Sources and Manifestations", The University of Chicago Press, Chicago and London.

Peslak, A.R. (2005) "The Educational Productivity Paradox. Communicationsof the ACM", 48 (10), 111-114. http://dx.doi.org/10.1145/1089107.1089143.

Sahlberg, P., (2010) “The Secret to Finland's Success: Educating Teachers. Stanford Center for Opportunity Policy in Education”, September 2010, 1-8.

Schlte-Pelkum, J., Schweer, M. and Pollak, B. (2014) "Dyadic Trust Relations between Teachers and Students: An Empirical Study about Conditions and Effects of Perceived Trustworthiness in the Classroom from a Differential Perspective”, Beziehungen in Unterricht und Schule, 2014 (5), 1-14.

Stehlik, T. (2016) Is "Pedagogical Love" the Secret to Finland's Educational Success? http:// www.aare.edu.au/blog/?p=1578 Retrieved 30 May 2016.

Tokumasu, S. and Watanabe, C. (2008) "Institutional Structure Leading to the Similarity and Disparity in Innovation Inducement in EU 15 Countries", Journal of Services Research, 8 (1), 5-42.

UNESCO (2003) "Towards Policies for Integrating Information and Communication Technologies into Education", UNESCO, Paris.

Varkey Gems Foundation (VGF) (2014) 2013 Global Teacher Status Index, VGF, London.

Watanabe, C., Naveed, K. and Zhao, W. (2014) "Structural Source of the Trap of ICT Advancement: Lessons from World ICT Top Leaders", Journal of Technology Management for Growing Economies, 5(2), 49-71.

Watanabe, C., Naveed, K. and Zhao, W. (2014) "New Paradigm of ICT Productivity: Increasing Role of Un-captured GDP and Growing Anger of Consumers”, Technology in Society, 41, 21-44.

Watanabe, C., Naveed, K. and Neittaanmäki, P., (2015) "Dependency on Un-captured GDP as a Source of Resilience beyond Economic Value in Countries with Advanced ICT Infrastructure”, Similarity and Disparities between Finland and Singapore. Technology in Society, 42, 104-122. http://dx.doi.org/10.1016/j.techsoc.2015.04.003.

Watanabe, C., Naveed, K., Neittaanmäki, P. and Tou, Y. (2016) "Operationalization of Uncaptured GDP: The Innovation Stream under New Global Mega-trends”, Technology in Society, 45, 58-77. http://dx.doi.org/10.1016/j.techsoc.2016.02.008.

Watanabe, C., Naveed, K. and Neittaanmäki, P. (2016) "Co-evolution of Three Mega-trends
Co-evolution

between Trust in

Teachers

Journal of Technology Management for Growing Economies, Volume 7, Number 2, October 2016 
Watanabe, $\mathrm{C}$.

Naveed, K.

Neittaanmäki, P.
Natures Un-captured GDP: Uber's Ride-sharing Revolution”, Technology in Society, 46, 164-185. http://dx.doi.org/10.1016/j.techsoc.2016.06.004.

World Economic Forum (WEF), 2013. The Global Competitiveness Report 2013-2014. WEF, Geneva.

World Economic Forum (WEF), 2013. The Global Information Technology Report. WEF, Geneva.

Zhao, W, Watanabe, C. and Tou, Y. (2013) Co-emergence of Institutional Innovation Navigates the New Normal in Growing Economies. Journal of Technology Management for Growing Economies, 4 (1), 69-81.

Zitter I. and Hoeve, A., (2012) "Hybrid Learning Environments: Merging Learning and Work Processes to Facilitate Knowledge Integration and Transitions", OECD Education Working Papers, No. 81, OECD Publishing. 
APPENDIX 1 LEVEL OF ICT ADVANCEMENT IN THE WORLD

Table A1 Level of ICT Advancement by NRI in 144 Countries (2013)

\begin{tabular}{|c|c|c|c|c|c|c|c|c|}
\hline Rank & Country & $\begin{array}{l}\text { Va- } \\
\text { lue }\end{array}$ & Rank & Country & $\begin{array}{l}\text { Va- } \\
\text { lue }\end{array}$ & Rank & Country & Value \\
\hline 1 & Finland & 5.98 & 51 & Croatia & 4.17 & 101 & $\begin{array}{l}\text { Iran, Is- } \\
\text { lamic Rep. }\end{array}$ & 3.43 \\
\hline 2 & Singapore & 5.96 & 52 & Uruguay & 4.16 & 102 & Guatemala & 3.42 \\
\hline 3 & Sweden & 5.91 & 53 & Costa Rica & 4.15 & 103 & Peru & 3.39 \\
\hline 4 & $\begin{array}{l}\text { Nether- } \\
\text { lands }\end{array}$ & 5.81 & 54 & $\begin{array}{l}\text { Russian Fede- } \\
\text { ration }\end{array}$ & 4.13 & 104 & Paraguay & 3.37 \\
\hline 5 & Norway & 5.66 & 55 & Mauritius & 4.12 & 105 & Pakistan & 3.35 \\
\hline 6 & $\begin{array}{l}\text { Switzer- } \\
\text { land }\end{array}$ & 5.66 & 56 & Azerbaijan & 4.11 & 106 & Cambodia & 3.34 \\
\hline 7 & UK & 5.64 & 57 & $\begin{array}{l}\text { Brunei Darus- } \\
\text { salam }\end{array}$ & 4.11 & 107 & Senegal & 3.33 \\
\hline 8 & Denmark & 5.58 & 58 & China & 4.03 & 108 & Venezuela & 3.33 \\
\hline 9 & USA & 5.57 & 59 & Mongolia & 4.01 & 109 & Honduras & 3.32 \\
\hline 10 & $\begin{array}{l}\text { Taiwan, } \\
\text { China }\end{array}$ & 5.47 & 60 & Brazil & 3.97 & 110 & Uganda & 3.30 \\
\hline 11 & $\begin{array}{l}\text { Korea, } \\
\text { Rep. }\end{array}$ & 5.46 & 61 & $\begin{array}{l}\text { Slovak Re- } \\
\text { public }\end{array}$ & 3.95 & 111 & Namibia & 3.29 \\
\hline 12 & Canada & 5.44 & 62 & Kuwait & 3.94 & 112 & Tajikistan & 3.29 \\
\hline 13 & Germany & 5.43 & 63 & Mexico & 3.93 & 113 & Nigeria & 3.27 \\
\hline 14 & $\begin{array}{l}\text { Hong } \\
\text { Kong }\end{array}$ & 5.40 & 64 & Greece & 3.93 & 114 & $\begin{array}{l}\text { Bangla- } \\
\text { desh }\end{array}$ & 3.22 \\
\hline 15 & Israel & 5.39 & 65 & Georgia & 3.93 & 115 & Zambia & 3.19 \\
\hline 16 & $\begin{array}{l}\text { Luxem- } \\
\text { bourg }\end{array}$ & 5.37 & 66 & Colombia & 3.91 & 116 & Zimbabwe & 3.17 \\
\hline 17 & Iceland & 5.31 & 67 & $\begin{array}{l}\text { Macedonia, } \\
\text { FYR }\end{array}$ & 3.89 & 117 & Suriname & 3.13 \\
\hline 18 & Australia & 5.26 & 68 & India & 3.88 & 118 & $\begin{array}{l}\text { Kyrgyz } \\
\text { Republic }\end{array}$ & 3.09 \\
\hline 19 & Austria & 5.25 & 69 & Sri Lanka & 3.88 & 119 & Bolivia & 3.01 \\
\hline 20 & $\begin{array}{l}\text { New Zea- } \\
\text { land }\end{array}$ & 5.25 & 70 & South Africa & 3.87 & 120 & $\begin{array}{l}\text { Côte } \\
\text { d'Ivoire }\end{array}$ & 3.00 \\
\hline 21 & Japan & 5.24 & 71 & Bulgaria & 3.87 & 121 & Gabon & 2.97 \\
\hline 22 & Estonia & 5.12 & 72 & $\begin{array}{l}\text { Trinidad and } \\
\text { Tobago }\end{array}$ & 3.87 & 122 & Mali & 2.97 \\
\hline 23 & Qatar & 5.10 & 73 & Ukraine & 3.87 & 123 & Benin & 2.97 \\
\hline
\end{tabular}

Journal of Technology Management for Growing Economies, Volume 7, Number 2, October 2016
Co-evolution between Trust in Teachers 
Watanabe, C.

Naveed, K.

Neittaanmäki, P.

\begin{tabular}{|c|c|c|c|c|c|c|c|c|}
\hline Rank & Country & $\begin{array}{l}\text { Val- } \\
\text { ue }\end{array}$ & Rank & Country & $\begin{array}{r}\text { Val- } \\
\text { ue }\end{array}$ & Rank & Country & Value \\
\hline 24 & Belgium & 5.10 & 74 & Thailand & 3.86 & 124 & Cameroon & 2.95 \\
\hline 25 & UAE & 5.07 & 75 & Romania & 3.86 & 125 & Nicaragua & 2.93 \\
\hline 26 & France & 5.06 & 76 & Indonesia & 3.84 & 126 & Nepal & 2.93 \\
\hline 27 & Ireland & 5.05 & 77 & Moldova & 3.84 & 127 & Tanzania & 2.92 \\
\hline 28 & Malta & 4.90 & 78 & Bosnia & 3.80 & 128 & Ethiopia & 2.85 \\
\hline 29 & Bahrain & 4.83 & 79 & Seychelles & 3.80 & 129 & Malawi & 2.83 \\
\hline 30 & Malaysia & 4.82 & 80 & Egypt & 3.78 & 130 & $\begin{array}{l}\text { Burkina } \\
\text { Faso }\end{array}$ & 2.80 \\
\hline 31 & $\begin{array}{l}\text { Saudi } \\
\text { Arabia }\end{array}$ & 4.82 & 81 & Cape Verde & 3.78 & 131 & Algeria & 2.78 \\
\hline 32 & Lithuania & 4.72 & 82 & Armenia & 3.76 & 132 & Libya & 2.77 \\
\hline 33 & Portugal & 4.67 & 83 & Albania & 3.75 & 133 & $\begin{array}{l}\text { Mozam- } \\
\text { bique }\end{array}$ & 2.76 \\
\hline 34 & Chile & 4.59 & 84 & Vietnam & 3.74 & 134 & Timor-leste & 2.72 \\
\hline 35 & Cyprus & 4.59 & 85 & Jamaica & 3.74 & 135 & Mauritania & 2.71 \\
\hline 36 & Puerto Rico & 4.55 & 86 & Philippines & 3.73 & 136 & Swaziland & 2.69 \\
\hline 37 & Slovenia & 4.53 & 87 & Serbia & 3.70 & 137 & Madagascar & 2.69 \\
\hline 38 & Spain & 4.51 & 88 & Rwanda & 3.68 & 138 & Lesotho & 2.68 \\
\hline 39 & Barbados & 4.49 & 89 & Morocco & 3.64 & 139 & Yemen & 2.63 \\
\hline 40 & Oman & 4.48 & 90 & $\begin{array}{l}\text { Dominican } \\
\text { Republic }\end{array}$ & 3.62 & 140 & Guinea & 2.61 \\
\hline 41 & Latvia & 4.43 & 91 & Ecuador & 3.58 & 141 & Haiti & 2.58 \\
\hline 42 & $\begin{array}{l}\text { Czech } \\
\text { Republic }\end{array}$ & 4.38 & 92 & Kenya & 3.54 & 142 & Chad & 2.53 \\
\hline 43 & Kazakhstan & 4.32 & 93 & El Salvador & 3.53 & 143 & $\begin{array}{l}\text { Sierra } \\
\text { Leone }\end{array}$ & 2.53 \\
\hline 44 & Hungary & 4.29 & 94 & Lebanon & 3.53 & 144 & Burundi & 2.30 \\
\hline 45 & Turkey & 4.22 & 95 & Ghana & 3.51 & & & \\
\hline 46 & Panama & 4.22 & 96 & Botswana & 3.50 & & & \\
\hline 47 & Jordan & 4.20 & 97 & Liberia & 3.48 & & & \\
\hline 48 & $\begin{array}{l}\text { Montene- } \\
\text { gro }\end{array}$ & 4.20 & 98 & Gambia, The & 3.47 & & & \\
\hline 49 & Poland & 4.19 & 99 & Argentina & 3.47 & & & \\
\hline 50 & Italy & 4.18 & 100 & Guyana & 3.45 & & & \\
\hline
\end{tabular}

Source: The Global Information Technology Report 2013 (World Economic Forum, 2013). 
Table A2 Level of ICT Advancement by NRI in 20 Countries (2012-2015)

\begin{tabular}{|l|c|c|c|c|c|}
\hline Country & 2012-15 average & 2012 & 2013 & 2014 & 2015 \\
\hline Finland & 5.96 & 5.81 & 5.98 & 6.04 & 6.00 \\
\hline Singapore & 5.95 & 5.86 & 5.96 & 5.97 & 6.00 \\
\hline Netherlands & 5.75 & 5.60 & 5.81 & 5.79 & 5.80 \\
\hline Switzerland & 5.65 & 5.61 & 5.66 & 5.62 & 5.70 \\
\hline USA & 5.59 & 5.56 & 5.57 & 5.61 & 5.60 \\
\hline UK & 5.57 & 5.50 & 5.64 & 5.54 & 5.60 \\
\hline Korea & 5.49 & 5.47 & 5.46 & 5.54 & 5.50 \\
\hline Germany & 5.44 & 5.32 & 5.43 & 5.50 & 5.50 \\
\hline Japan & 5.38 & 5.25 & 5.24 & 5.41 & 5.60 \\
\hline Israel & 5.36 & 5.24 & 5.39 & 5.42 & 5.40 \\
\hline New Zealand & 5.35 & 5.36 & 5.25 & 5.27 & 5.50 \\
\hline France & 5.12 & 5.12 & 5.06 & 5.09 & 5.20 \\
\hline Portugal & 4.73 & 4.63 & 4.67 & 4.73 & 4.90 \\
\hline Spain & 4.61 & 4.54 & 4.51 & 4.69 & 4.70 \\
\hline Czech Republic & 4.43 & 4.33 & 4.38 & 4.49 & 4.50 \\
\hline Turkey & 4.25 & 4.07 & 4.22 & 4.30 & 4.40 \\
\hline Italy & 4.21 & 4.17 & 4.18 & 4.18 & 4.30 \\
\hline China & 4.10 & 4.11 & 4.03 & 4.05 & 4.20 \\
\hline Greece & 3.99 & 3.99 & 3.93 & 3.95 & 4.10 \\
\hline Brazil & 3.94 & 3.92 & 3.97 & 3.98 & 3.90 \\
\hline
\end{tabular}

Value measured by the Networked Readiness Index (NRI).

Source: The Global Information Technology Report 2012, 2013, 2014, 2015 (World Economic Forum, 2012, 2013, 2014, 2015).

Table A3: Co-evolutionary Structure: Advancement of ICT (2013)

\begin{tabular}{|c|l|c|c|l|c|c|l|l|l|l|c|}
\hline & Country & Value & & Country & Value & & Country & Value & & Country & Value \\
\hline 1 & Finland & 5.98 & 9 & USA & 5.57 & 21 & Japan & 5.24 & 45 & Turkey & 4.22 \\
\hline 2 & Singapore & 5.96 & 11 & Korea & 5.46 & 26 & France & 5.06 & 50 & Italy & 4.18 \\
\hline 4 & $\begin{array}{l}\text { Nether- } \\
\text { lands }\end{array}$ & 5.81 & 13 & $\begin{array}{l}\text { Germa- } \\
\text { ny }\end{array}$ & 5.43 & 33 & Portugal & 4.67 & 58 & China & 4.03 \\
\hline 6 & Switzerland & 5.66 & 15 & Israel & 5.39 & 38 & Spain & 4.51 & 60 & Brazil & 3.97 \\
\hline 7 & UK & 5.64 & 20 & $\begin{array}{l}\text { New } \\
\text { Zealand }\end{array}$ & 5.25 & 42 & $\begin{array}{l}\text { Czech } \\
\text { Republic }\end{array}$ & 4.38 & 64 & Greece & 3.93 \\
\hline
\end{tabular}

Figures in the left hand side indicate world rank out of 144 countries (see Table A1). Source: The Global Information Technology Report 2013 (World Economic Forum, 2013).
Co-evolution between Trust in Teachers 
Watanabe, $\mathrm{C}$. Naveed, K.

Neittaanmäki, P.

Table A4: Co-evolutionary Structure: Higher Education Level (2013)

\begin{tabular}{|l|r|l|r|l|r|l|r|}
\hline Country & Value & Country & Value & Country & Value & $\begin{array}{l}\text { Coun- } \\
\text { try }\end{array}$ & \multicolumn{1}{l|}{ Value } \\
\hline Finland & 6.27 & USA & 5.75 & France & 5.21 & Greece & 4.81 \\
\hline Singapore & 5.91 & New Zealand & 5.68 & Spain & 5.19 & Italy & 4.75 \\
\hline Germany & 5.90 & UK & 5.45 & Portugal & 5.15 & Turkey & 4.29 \\
\hline Switzerland & 5.88 & Korea & 5.41 & Israel & 5.00 & China & 4.23 \\
\hline Netherlands & 5.78 & Japan & 5.28 & $\begin{array}{l}\text { Republic } \\
\text { Rech }\end{array}$ & 4.85 & Brazil & 4.22 \\
\hline
\end{tabular}

Source: The Global Competitiveness Report 2013-2014 (World Economic Forum, 2013).

Table A5: Co-evolutionary Structure: Trust in Teachers (2013)

\begin{tabular}{|lr|lr|lr|lr|}
\hline Country & Value & Country & Value & Country & Value & Country & Value \\
\hline Brazil & 7.10 & Portugal & 6.62 & Turkey & 6.50 & Germany & 5.96 \\
& & & & & & \\
Czech & \\
Finland & 7.05 & Singapore & 6.60 & UK & 6.40 & Republic & 5.94 \\
Spain & 6.86 & Netherlands & 6.56 & France & 6.15 & Korea & 5.40 \\
& & New Zea- & & Switzer- & & & \\
China & 6.74 & land & 6.54 & land & 6.10 & Japan & 5.35 \\
USA & 6.68 & Italy & 6.52 & Greece & 6.08 & Israel & 5.20 \\
\hline
\end{tabular}

Source: 2013 Global Teacher Status Index (Varkey GEMS Foundation, 2014).

Table A6: Composition of Higher Education Level in 20 Countries (2013)

\begin{tabular}{|c|c|c|c|c|c|c|c|c|c|}
\hline Country & $\begin{array}{l}\text { 5th pillar: } \\
\text { Higher } \\
\text { educa- } \\
\text { tion and } \\
\text { training }\end{array}$ & $\begin{array}{l}5.01 \\
\text { Secondary } \\
\text { education } \\
\text { enrollment, } \\
\text { gross \% }\end{array}$ & $\begin{array}{c}5.02 \\
\text { Tertiary } \\
\text { education } \\
\text { enroll- } \\
\text { ment, } \\
\text { gross \% }\end{array}$ & $\begin{array}{l}5.03 \\
\text { Quality } \\
\text { of the } \\
\text { education } \\
\text { system }\end{array}$ & $\begin{array}{c}5.04 \\
\text { Quality of } \\
\text { math and } \\
\text { science } \\
\text { education }\end{array}$ & $\begin{array}{c}5.05 \\
\text { Quality } \\
\text { of man- } \\
\text { agement } \\
\text { schools }\end{array}$ & $\begin{array}{c}5.06 \\
\text { Internet } \\
\text { access in } \\
\text { schools }\end{array}$ & $\begin{array}{l}5.07 \text { Avail- } \\
\text { ability of } \\
\text { research } \\
\text { and } \\
\text { training } \\
\text { services }\end{array}$ & $\begin{array}{c}5.08 \\
\text { Extent } \\
\text { of staff } \\
\text { training }\end{array}$ \\
\hline Finland & 6.27 & 107.97 & 95.15 & 5.93 & 6.26 & 5.64 & 6.57 & 5.87 & 5.52 \\
\hline Singapore & 5.91 & 107.00 & 72.00 & 5.77 & 6.29 & 5.75 & 6.30 & 5.44 & 5.23 \\
\hline Germany & 5.90 & 103.32 & - & 5.14 & 5.05 & 5.10 & 5.03 & 6.10 & 5.12 \\
\hline Switzerland & 5.88 & 95.46 & 56.75 & 5.98 & 5.80 & 6.09 & 6.11 & 6.47 & 5.57 \\
\hline Netherlands & 5.78 & 121.46 & 65.41 & 5.17 & 5.31 & 5.66 & 6.25 & 6.09 & 5.14 \\
\hline USA & 5.75 & 96.04 & 94.81 & 4.63 & 4.41 & 5.49 & 5.95 & 5.67 & 4.96 \\
\hline $\begin{array}{l}\text { New } \\
\text { Zealand }\end{array}$ & 5.68 & 119.08 & 82.56 & 5.19 & 5.38 & 5.16 & 5.67 & 4.93 & 4.95 \\
\hline UK & 5.45 & 105.34 & 59.75 & 4.62 & 4.37 & 5.89 & 6.16 & 5.61 & 4.73 \\
\hline Korea & 5.41 & 97.08 & 103.11 & 3.82 & 5.10 & 4.45 & 6.11 & 4.81 & 4.21 \\
\hline Japan & 5.28 & 102.20 & 59.74 & 4.10 & 4.66 & 4.04 & 5.16 & 5.52 & 5.35 \\
\hline
\end{tabular}

Journal of Technology Management for Growing Economies, Volume 7, Number 2, October 2016 


\begin{tabular}{|l|r|r|r|r|r|r|r|r|r|}
\hline France & $\mathbf{5 . 2 1}$ & 113.59 & 57.67 & 4.21 & 5.19 & 5.80 & 4.41 & 5.42 & 4.33 \\
\hline Spain & $\mathbf{5 . 1 9}$ & 128.52 & 82.63 & 3.60 & 3.86 & 5.83 & 4.92 & 4.82 & 3.72 \\
\hline Portugal & $\mathbf{5 . 1 5}$ & 109.10 & 65.49 & 3.96 & 4.07 & 5.52 & 5.67 & 5.00 & 4.01 \\
\hline Israel & $\mathbf{5 . 0 0}$ & 102.12 & 62.48 & 4.00 & 4.03 & 4.68 & 5.08 & 4.77 & 4.24 \\
\hline $\begin{array}{l}\text { Czech } \\
\text { Republic }\end{array}$ & $\mathbf{4 . 8 5}$ & 90.78 & 64.85 & 3.69 & 3.96 & 3.95 & 5.79 & 5.00 & 4.03 \\
\hline Greece & $\mathbf{4 . 8 1}$ & 109.46 & 89.38 & 3.10 & 4.28 & 3.85 & 3.91 & 3.83 & 3.47 \\
\hline Italy & $\mathbf{4 . 7 5}$ & 100.40 & 64.98 & 3.64 & 4.26 & 4.98 & 3.67 & 4.79 & 3.21 \\
\hline Turkey & $\mathbf{4 . 2 9}$ & 82.11 & 55.42 & 3.41 & 3.52 & 3.76 & 4.45 & 4.23 & 4.05 \\
\hline China & $\mathbf{4 . 2 3}$ & 81.36 & 26.79 & 4.02 & 4.42 & 4.11 & 5.32 & 4.36 & 4.26 \\
\hline Brazil & $\mathbf{4 . 2 2}$ & 105.83 & 25.63 & 2.98 & 2.56 & 4.54 & 3.60 & 4.71 & 4.30 \\
\hline
\end{tabular}

Co-evolution between Trust in Teachers

Source: The Global Competitiveness Report 2013-2014 (World Economic Forum, 2013).

\section{Appendix 2 Estimate of Logistic Growth Function for ICT-driven Higher Education in 120 Countries in 2013}

ICT-driven Educational Development towards digitally-rich learning environments in 120 Countries in 2013 is demonstrated as follows (Fig. 2):

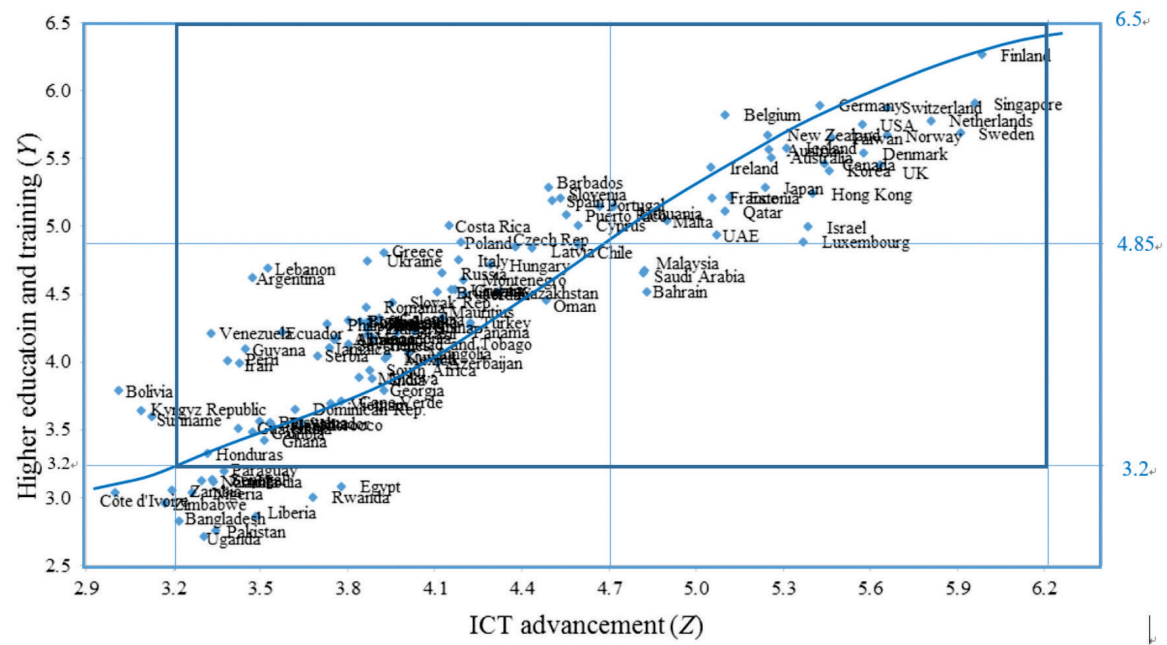

Figure A1: ICT-driven Educational Development in 120 Countries (2013). Sources: Same as Fig. 2.

Focusing on the scope between $(Z, Y)$ from $(3.2,3.2)$ to $(6.2,6.5)$ as highlighted in Fig. A1, since it is observed that the above trajectory behaves sigmoid growth, following logistic growth function was estimated as depicted in equation (2) in 3.1 . 
Watanabe, C.

Naveed, K.

Neittaanmäki, P.

$$
Y=\frac{N}{1+b e^{-a Z}}
$$

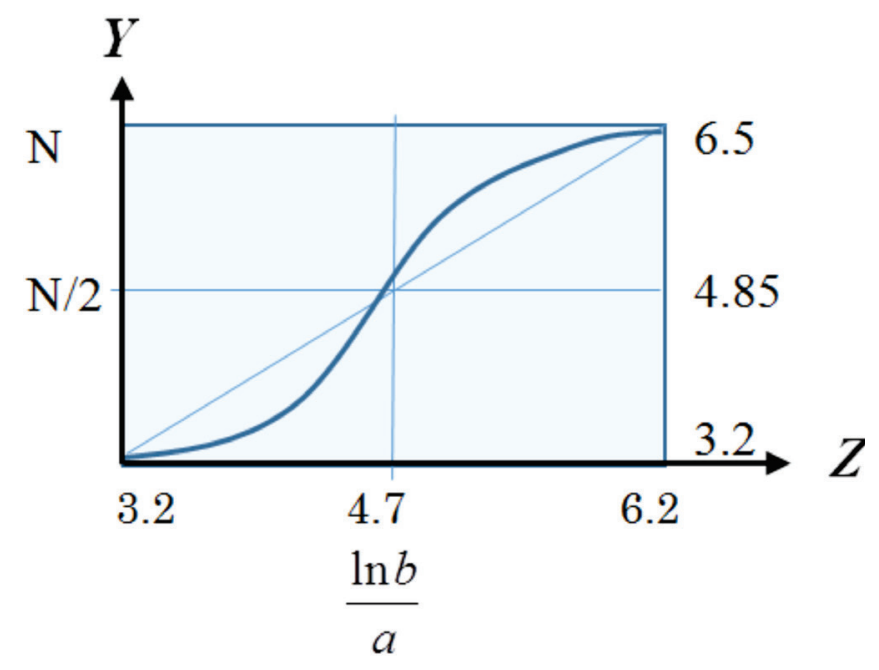

Figure A2: Estimated Logistic Growth Function.

With the observation that carrying capacity and inflection point of the sigmoid curve are estimated as 6.5 and 4.7, respectively, by means of heuristic spline interpolation approach, following logistic growth function for 120 countries in 130 was estimated.

$$
Y^{\prime}=\frac{3.30}{1+13.50 e^{-1.74 Z^{\prime}}} \text { where } Y^{\prime}=Y-3.20, Z^{\prime}=Z-3.20 \text {. }
$$

This estimated function behaves similar to observed sigmoid curve as $N=3.30+3.20=6.50$, inflection point $\bar{Z}=\frac{\ln b}{a}+3.20=1.50+3.20=4.70$ Thus, estimated function is considered to demonstrate the ICT-driven education development trajectory in 120 countries in 2013.

\section{APPENDIX 3 GLOBAL TEACHER STATUS INDEX}

Aiming at identifying how the level of respect for teachers effects to the educational performance, the Varkey Gems Foundation conducted a survey to 1,000 representative respondents in each of the following 21 countries: Brazil, China, Czech Republic, Egypt, Finland, France, Germany, Greece, Israel, Italy, Japan, the Netherlands, New Zealand, Portugal, Turkey, Singapore, South Korea, Spain, Switzerland, UK and USA. These countries were chosen on their performance in PISA and TIMASS assessments to represent each major continent and as representative of different standards of education systems.

Journal of Technology Management for Growing Economies, Volume 7, Number 2, October 2016 
This paper depended on the rating of "Trusting teachers to deliver education." To address this issue the survey asked respondents to rate (rating out of 10, $1=$ low rating, 10 = high rating) the education system in their own country to judge whether they thought teachers could be trusted to deliver a good education.

In this paper 20 countries out of 21 were compared excluding Egypt as its higher education and training level was too lower to compare with other 20 countries.
Co-evolution between Trust in Teachers

\section{APPENDIX 4 SCHEME OFTHE BI-POLARIZATION FATALITY OF LOGISTIC GROWTH}

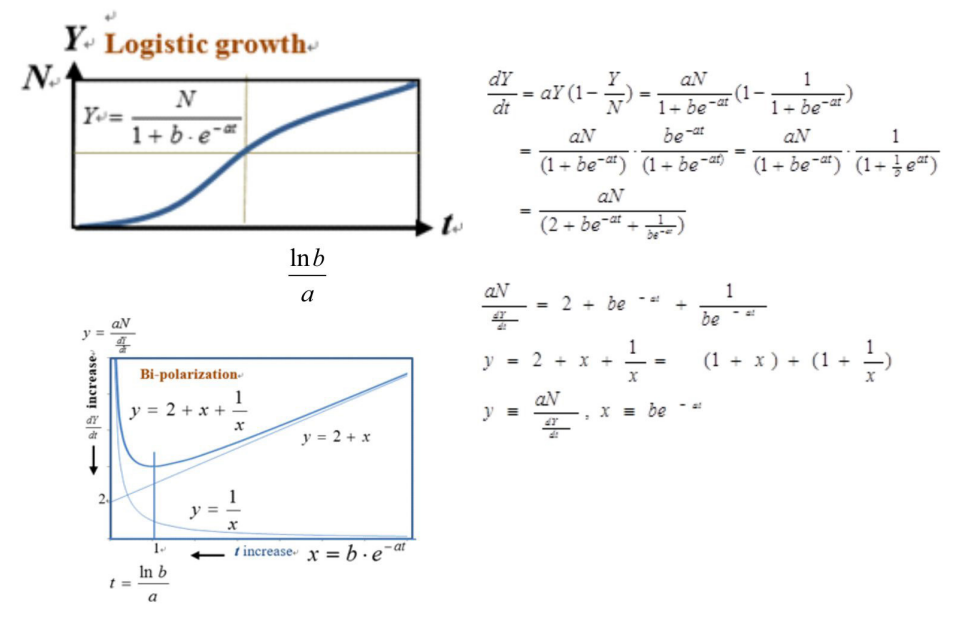

Fig.ure A3: Bi-polarization Fatal to Logistic Growth Function.

\section{$Z$ elasticity to $X$}

$$
\frac{d \mathrm{~h} X}{d \mathrm{~h} Z}=\frac{d \mathrm{~h} X}{d \mathrm{~h} Y} \cdot \frac{d \mathrm{~h} Y}{d \mathrm{~h} Z}=\frac{d \mathrm{~h} X}{d \mathrm{~h} Y} \cdot \frac{d}{\mathbb{Z}} \cdot \frac{Z}{Y}=\frac{d \mathrm{~h} X}{d \mathrm{~h} Y} \cdot \frac{Z}{Y} \cdot \frac{d l}{\mathbb{Z}} \cdot \frac{d}{d l}=\frac{d \mathrm{~h} X}{d \mathrm{~h} Y} \cdot \frac{Z}{Y} \cdot \frac{d l}{\mathbb{Z}} \cdot\left(\frac{Y(N-Y)}{N}\right)^{2} \cdot \frac{1}{(2 Y-N)}
$$

Table A7: Classification of ICT Elasticity to Trust in 20 Countries (2013)

\begin{tabular}{|c|c|c|c|c|c|c|c|}
\hline \multirow{2}{*}{$\begin{array}{l}\text { Education } \\
\text { level } \\
\text { ICT } \\
\text { level }\end{array}$} & \multicolumn{3}{|c|}{$Y>\frac{N}{2}$} & \multicolumn{4}{|c|}{$Y<\frac{N}{2}$} \\
\hline & $\frac{d \ln X}{d \ln Y} \quad \frac{d y}{d Z}$ & $\frac{1}{(2 Y-N)}$ & $\frac{d \ln X}{d \ln Z}$ & $\frac{d \ln X}{d \ln Y}$ & $\frac{d y}{d Z}$ & $\frac{1}{(2 Y-N)}$ & $\frac{d \ln X}{d \ln Z}$ \\
\hline$Z>\frac{\ln b}{a}$ & $\begin{array}{c}+\quad+ \\
\text { ICT advancec }\end{array}$ & $\begin{array}{c}+ \\
12 \text { countri }\end{array}$ & + & & & & \\
\hline$Z<\frac{\ln b}{a}$ & $\begin{array}{c}+ \\
\text { ICT semi-adv }\end{array}$ & $\begin{array}{c}+ \\
\text { anced } 2 \text { co }\end{array}$ & $\begin{array}{c}- \\
\text { tries }\end{array}$ & $\begin{array}{c}- \\
\text { ICT gro }\end{array}$ & $\begin{array}{r}- \\
\text { wing }\end{array}$ & $\begin{array}{c}- \\
6 \text { countries }\end{array}$ & $=$ \\
\hline Reference & $\begin{array}{ll}\text { Fig. } 9 & \text { Fig. } 12 \\
\end{array}$ & Appendix & & Fig. 9 & Fig. 12 & Appendix & \\
\hline
\end{tabular}


Watanabe, C. Furthermore,

Naveed, K.

Neittaanmäki, P.

Table A8: Classification of ICT Elasticity to Higher Education in 20 Countries (2013)

116

\begin{tabular}{|c|c|c|c|c|c|c|}
\hline \multirow{3}{*}{$\begin{array}{l}\text { Education } \\
\text { level } \\
\text { ICT } \\
\text { level }\end{array}$} & \multicolumn{3}{|c|}{$Y>\frac{N}{2}$} & \multicolumn{3}{|c|}{$Y<\frac{N}{2}$} \\
\hline & $d \ln X$ & $d \ln Y$ & $d \ln Y$ & $d \ln X$ & $d \ln Y$ & $d \ln Y$ \\
\hline & $\overline{d \ln Z}$ & $\overline{d \ln X}$ & $\overline{d \ln Z}$ & $\overline{d \ln Z}$ & $\overline{d \ln X}$ & $\overline{d \ln Z}$ \\
\hline$Z>\frac{\ln b}{a}$ & \multicolumn{3}{|c|}{$\begin{array}{ccr}+ & + & + \\
\text { ICT advanced } & 12 \text { countries }\end{array}$} & & & \\
\hline$Z<\frac{\ln b}{a}$ & \multicolumn{3}{|c|}{$\begin{array}{ccc}- & + & - \\
\text { ICT semi-advanced } & 2 \text { countries }\end{array}$} & \multicolumn{3}{|c|}{ ICT advanced 6 countries } \\
\hline Reference & Table A & Fig. & & Table A & Fig & \\
\hline
\end{tabular}

